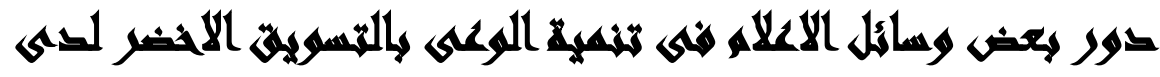

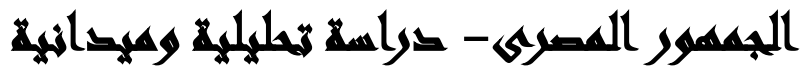 \\ [10]
}

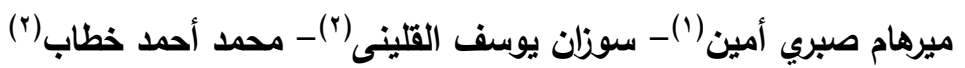

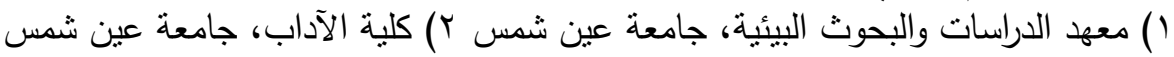

\section{المستخلس}

تهدف الدراسة الحالية إلى: رصد نأثنير اعلانات التسويق الاخضر على الإنى وعى الجمهور

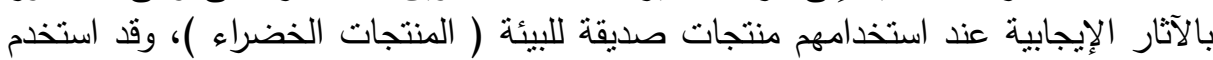

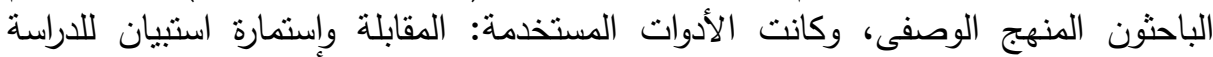

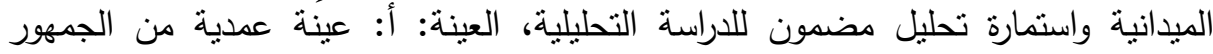

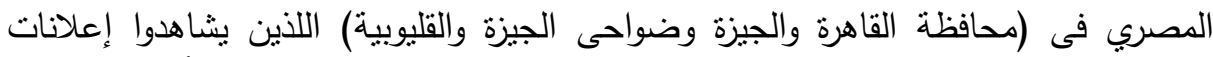

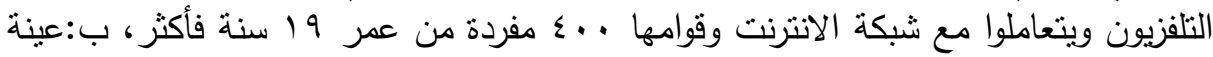

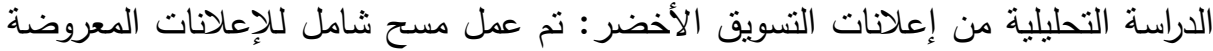

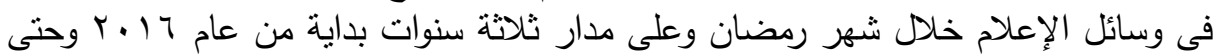

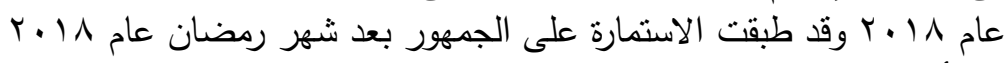

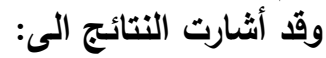

ا. عدم وجود فروق ذات دلالة إحصائية بين فئتي الدراسة (ذكور - اناث) حول مستوي وعي

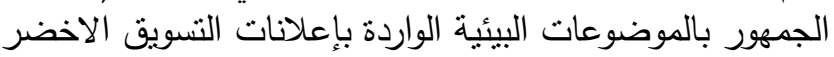

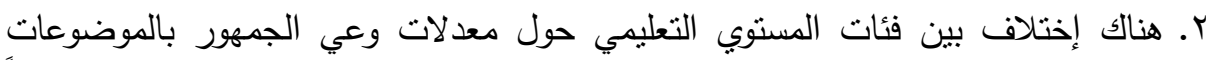

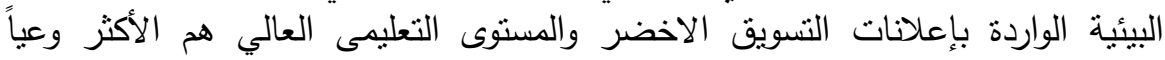

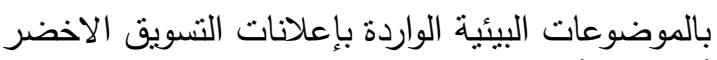

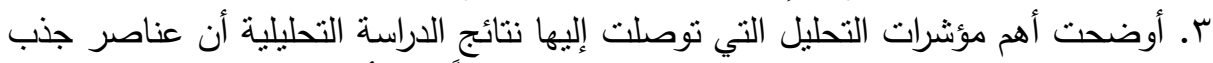

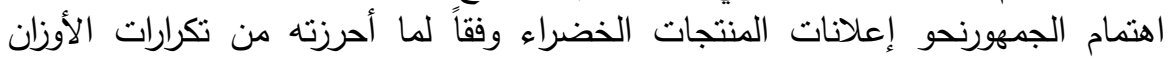

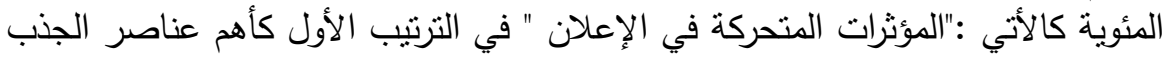

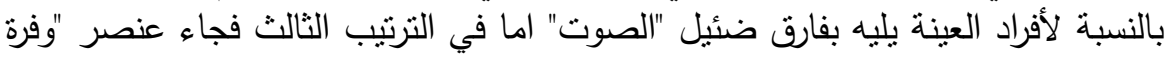

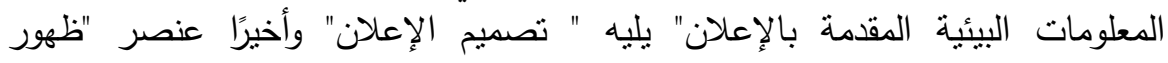

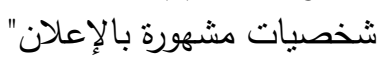

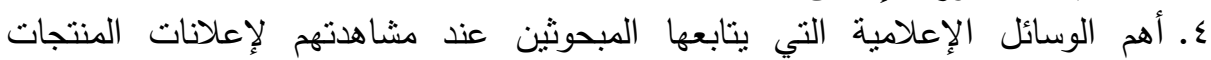

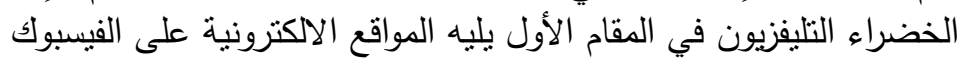

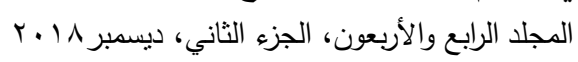


ه. جاء درجة إعتماد المبحوثين علي التليفزيون بالنسبة لعنصر "وفرة المعلومات البيئية

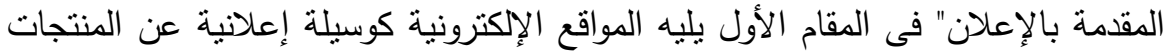

انتهت الاراسة الراهنة إلى التوصيات التالية: ضرورة زيادة اهتمام الثركات عند تسويقها

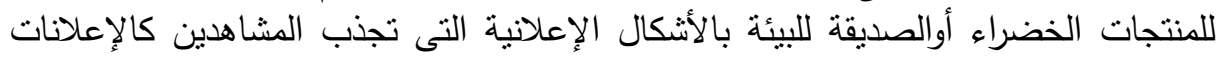
الغنائية والتمثيلية وتطويرها بحيث تزيد من اقناع المشاهدين وتحثهم على تغيير سلوكهم

الكلمات المفتاحية: وسائل الاعلام - نتمية الوعى - التسويق الاخضر -الجمهور المصرى

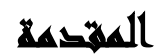

إن موضوع حماية البيئة من الضروريات الأساسية فى العالم ككل، لما لله من جوانب عديدة قد يؤدى إهمالها إلى نهاية حتمية للبشرية أجمع، فالبيئة بمعناها الواسع هى المى المكان الذي يعيش فيه الإنسان، ففيه كل صور حياته، لذللك فمن الضرورى توفير منظومة منكاملة

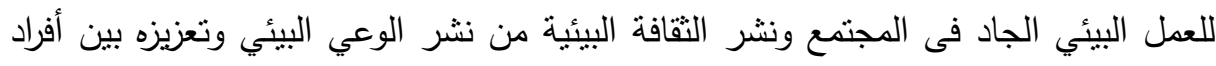

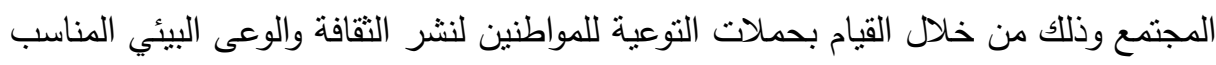

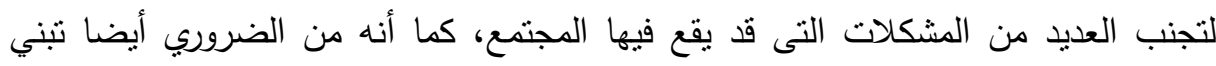
سياسات إنتاجية وتسويقية للمنتجات الصديقة للبية والمناسبة للمجتمع المصرى لإعادة تعديل

$$
\text { سلوك واتجاه الجمهور نحو البيئة . }
$$

فلعل مفهوم الحفاظ على البيئة ليس بالمفهوم الجديد عند أفراد المجتمع المصري، أيضا

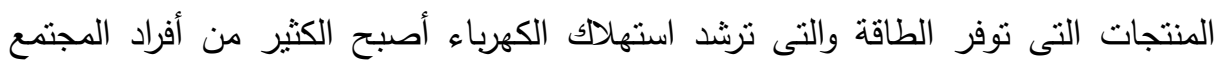

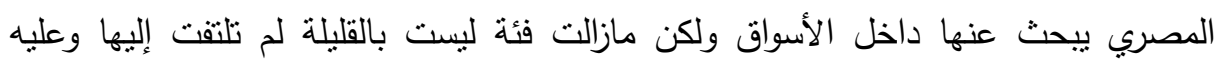

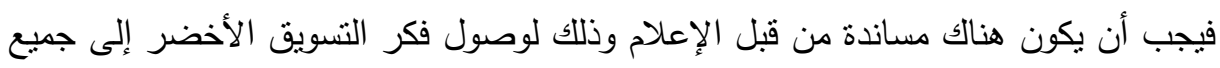
أفراد المجتمع بإختلاف مستوياتهم الإجتماعية والثقافية والتعليمية.

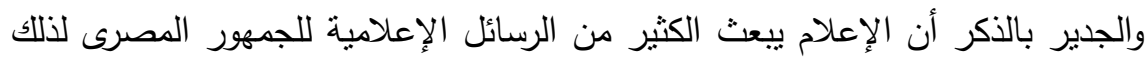

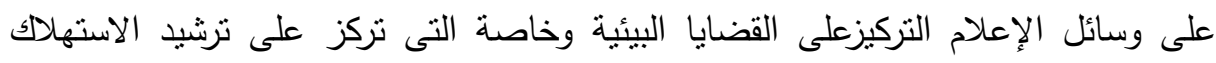

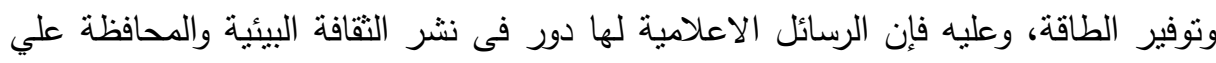

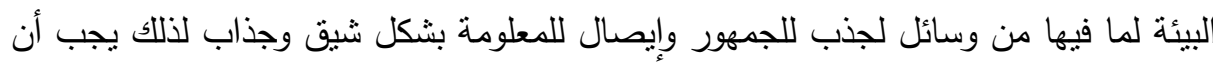


تكون الرسالة الاعلامية منميزة بعده صفات لتحقيق الهدف منها: كالوضوح والسهولة للوصول لأكبر عدد من الجمهور والمجتمع.

كما أن من العوامل الهامة لكى تتجح الرسالة الإعلامية دعم من قبل الجهات الرسمية

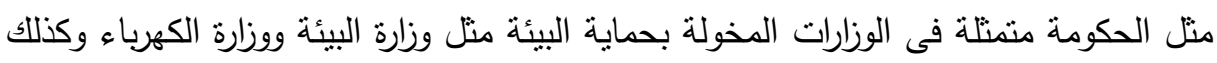
جهاز حماية المستهلك لتشجيع كل المؤسسات المجتمعية على التسويق الأخضر وضمان حصول البرامج التسويقية على التمويل اللازم لنشر برامج التوعية البيئية.

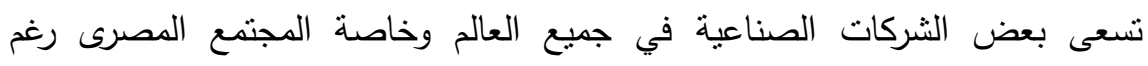
اختلاف طبيعة نشاطها إلى تحقيق زيادة فى أرباحها باستخدام طرق التسويق المختلفة لمنتجاتها من خلال وسائل الاعلام خاصة بعد توجه بعض الثركات لحماية البيئة من خلال

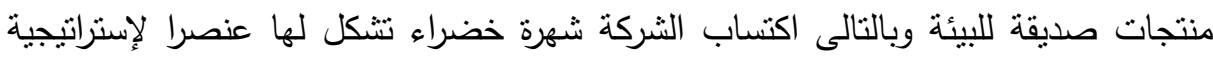
تتويع منتجاتها وزيادة أرباحها من أجل المنافسة الدولية مع الاخذ فى الإعتبار مواجهة

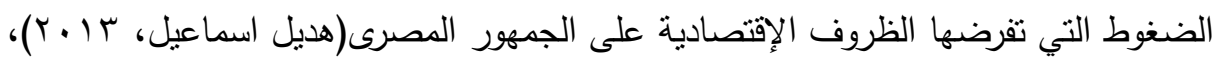
كما إتخذت الحكومة مجموعة من الإجراءات لكي يتواءم نشاط الشركات وتتمية الوعى البيئية لدى الجمهورعند استخدام المنتجات الخضراء وذلك عن طريق تطبيق مفهوم التسويق التهاء

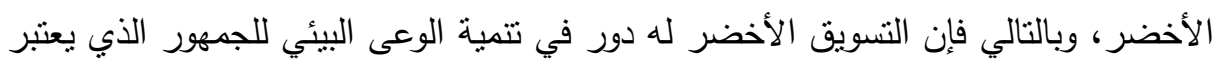
عنصر رئيسي من أجل تكوين ثقافة بيئية لدى الثركات. وتهدف الدراسة الحالية إلي التعرف علي دور وسائل الإعلام المصرية بما تملكه من

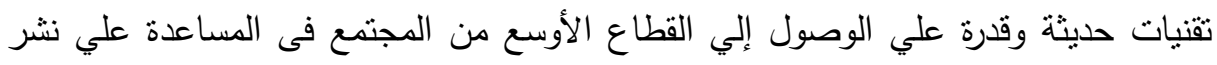

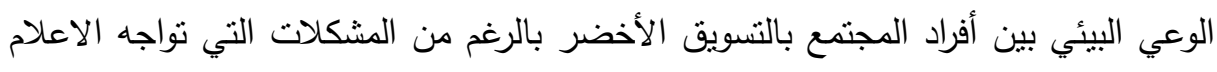

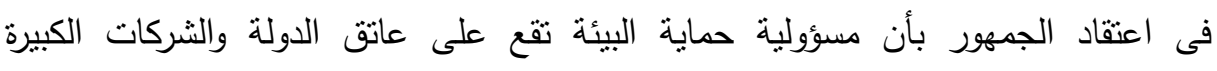

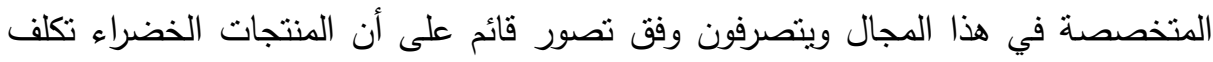
كثيراً مقارنة بمدخولاتهم المنخفضة فضلاً عن افتقارهم إلى التعليم والثقافة. 
من هنا تبرز أهمية هذه الدراسة لإرتباطها بتطور مفهوم التسويق الاخضر لدى الجمهور

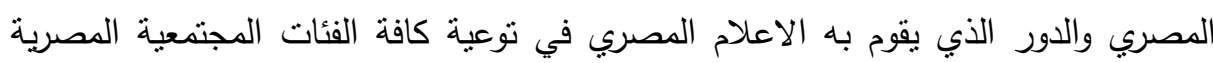
بمفهوم التسويق الأخضر وإنعكاساته على قناعاتهم ومعتقداتهم وسلوكياتهم اليومية.

\section{مئم}

من خلال بطاقة ملاحظة لمحتوى الاعلانات التى تهتم بالتسويق الاخضر من خلال التلفزيون كوسيلة إعلام قديمة والانترنت كوسيلة إعلام حديثة وخاصة فى المنتجات الصناعية،

وكذلك دراسة استطلاعية على عدد من الثباب وعددهم • ؛ فرد فوق 19 سنة

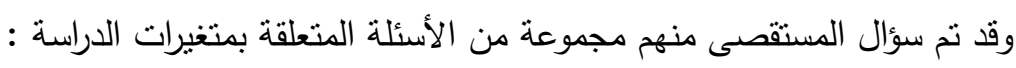

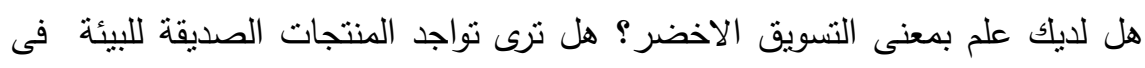
اللأسواق المصرية أمر هام ؟ هل انت راض عن وسائل الإعلام المختلفة للتوعية بالتسويق تلاجيق الاخضر؟ اذا نوافرت لديك فرصة اختبار ما بين منتجين منتج بيئى آمن ومنتج غير بيئى ايهما ستختار؟ واتضح من نتائج الاراسة الاستطلاعية: اقرت نسبة ه1\% من افراد العينة بأهمية المنتجات

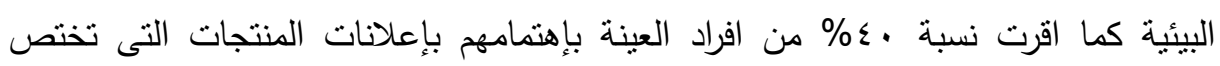
بالحفاظ على البيئة واقرت نسبة به\% من افراد العينة بعدم الرضا عن دور وسائل الاتصال

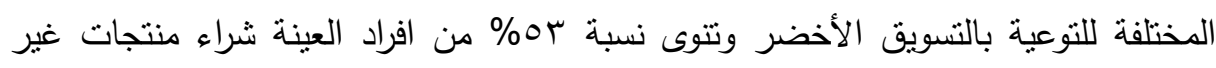
بيئية حتى لو تواجدت لهم فرصة للاختيار بين منتجات بيئية واخرى غير بيئية.

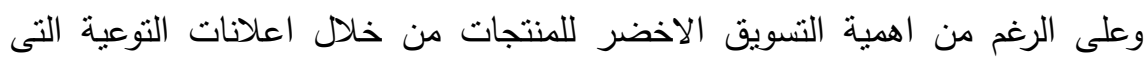

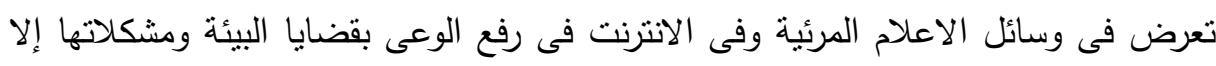

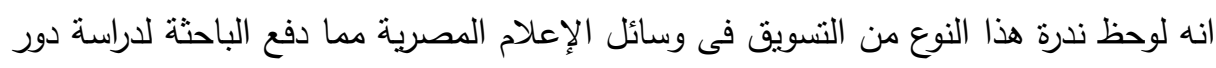

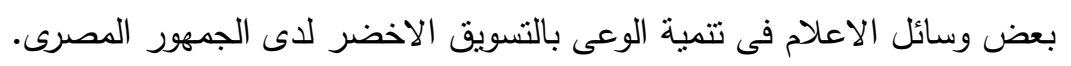




\section{أسئلا الهمهن التحليلهي}

ا ـ ما القوالب المستخدمة في إعلانات التسويق الأخضر؟

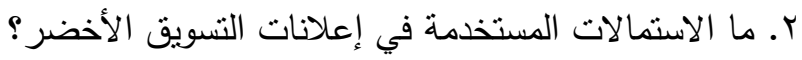

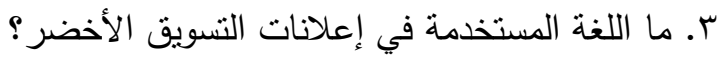
ع. ما الجمهور المستهدف في إعلانات التسويق الأخضر؟

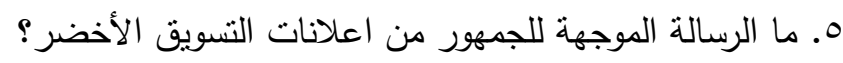

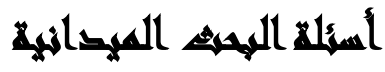

ا. ما الوسائل الذي يفضلها المبحوثين في متابعة إعلانات التسويق الأخضر في وسائل

$$
\text { الاعلام التقليدية والجديدة ؟ التص }
$$

r. مامدى متابعة المبحوثين لإعلانات التسويق الأخضر في وسائل الاعلام التقليدية والجديدة؟ - مائ

r. ما مدي وعي الجمهور المتعرض لإعلانات التسويق الأخضر بالموضوعات البيئية؟

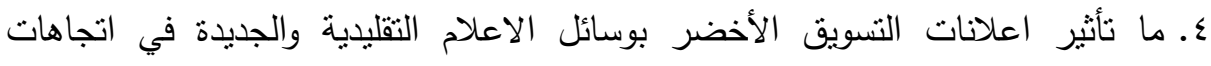

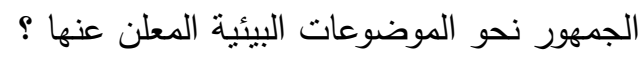

\section{هانه}

تهدف الدراسة بصفة أساسية إلى رصد تأثير اعلانات التسويق الاخضر على وعى الجمهور بالآثار الإيجابية عند استخدامهم لمنتجات صديقة للبيئة.

\section{أهمية الهمهي}

قد تفيد نتائج البحث الحالي القائمين على تخطيط الحملات الإعلانية بالآتى:

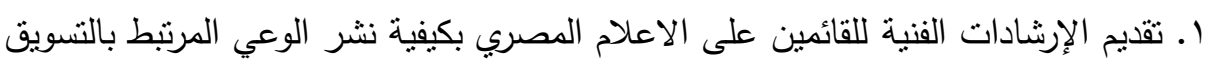

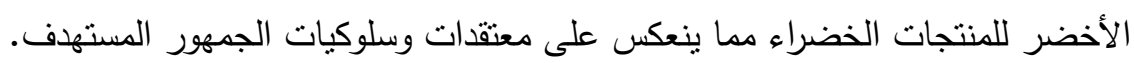

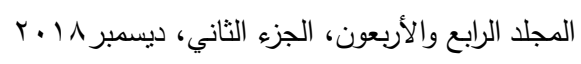


r. تحديد مظاهر وأبعاد التسويق الأخضر النى يجب أن نتنهجا بعض الثركات ثم قياسها من خلال أدوات الدراسة للاستفادة من نتائجها في الإرشاد على المستوى الوقائي والعلاجي لإني فى استخدام المنتجات الخضراء.

r. يقدم البحث مقياس للوعي البيئى لدى فئات مختلفة من الجمهور المصري عند استخدامهم لمنتجات صديقة للبيئة. ع. قد تسفر النتائج العلمية التى ينت التوصل إليها فى هذا البحث على أفضل الوسائل الإعلامية التى يعتمد عليها عند توصيل الرسالة الاعلانية.

\section{هورغ الهيه}

يحاول البحث الحالى التحقق من صحة الفروض التالية: الفرض الأول: وينص على: توجد فروق ذات دلالة احصائية بين مستوي وعي الجمهور

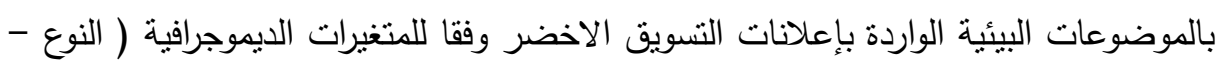

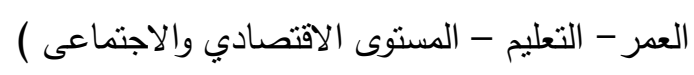

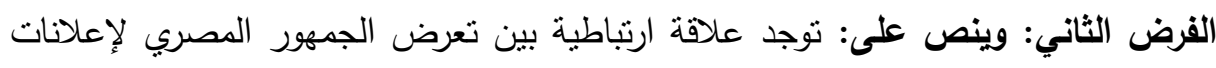
المنتجات الصديقة للبيئة (المنتجات الخضراء ) ومستوى الوعي بالموضوعات البيئية .

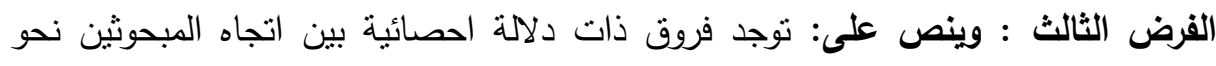

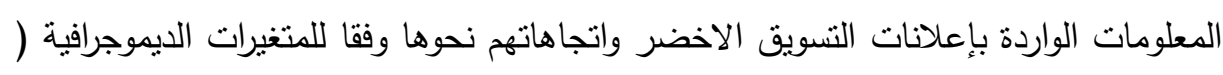

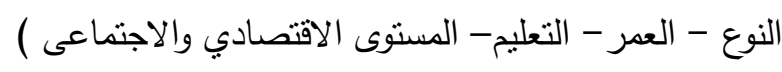
الفرض الرابع: وينص على: توجد علاقة ارتباطية بين المعلومات الواردة بإعلانات المنتجات الصديقة للبيئة (المنتجات الخضراء ) ومستوى إتجاهاتهم نحو الموضوعات البيئية 


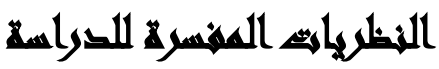

اعتمد البحث الحالى على نظريتين هما :

ا-نظرية الاعتماد على وسائل الإعلام في جزئها التطبيقى والتى تقيس العلاقة بين اعتماد الجمهور على وسائل الإعلام والتأثيرات الناتجة عن هذه العلاقة وخاصة التأثثرات المعرفية

$$
\text { والوجدانية والسلوكية. }
$$

r-نظرية الغرس التقافي لتحليل علاقة كثافة لتعرض والاعتماد على الإعلانات البيئية في

$$
\text { تكوين السلوك الإيجابى نحو البيئة. }
$$

\section{نظرية الإعتماد على وسائل الاعلام (Mass Media Dependency Theory ):}

تعتمد هذه الدراسة على مدخل الاعتماد على وسائل الاعلام في بنائها النظري وتطوير فروضها وذلك لكونها نظرية شاملة نقدم نظرة كلية للعلاقة بين الاتصال والرأي العام، فهي

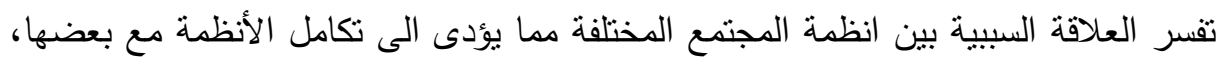

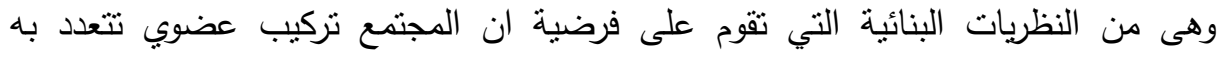

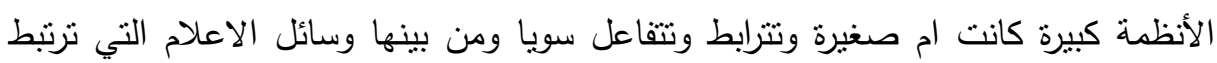

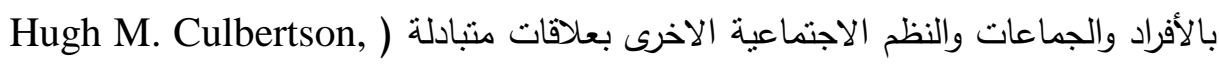

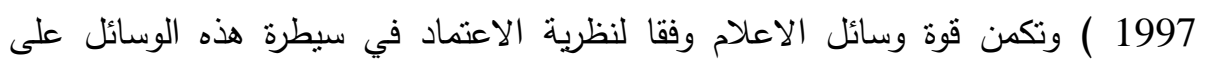

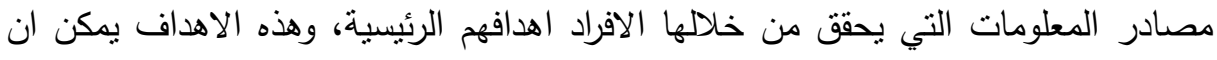

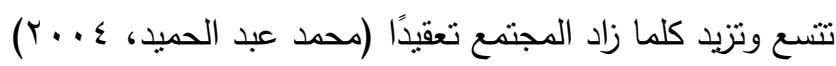

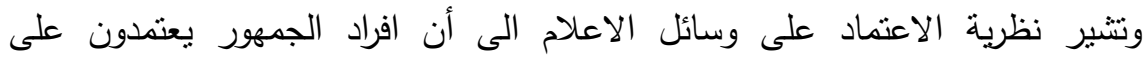
المعلومات التي توفرها وسائل الإعلام رغبة منهم في اثباع حاجاتهم وتحقيق رغباتهم

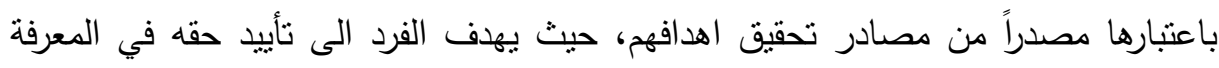
لاتخاذ القرارات الثخصية والاجتماعية المختلفة (John Downing,1996) ومن اجل الحصول على المعلومات تتفاعل وسائل الاعلام مع النظم الأخرى كالنظام الاقتصادي Stanly j. (السياسي والديني حيث تتشأ علاقة منبادلة بين وسائل الاعلام وهذه الأنظمة الاعلى 
ويرى الباحثون أن نظرية الاعتماد على وسائل الاعلام تعد مدخلاً نظرياً ملائماً لهذه الدراسة

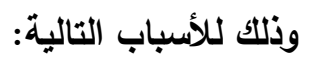

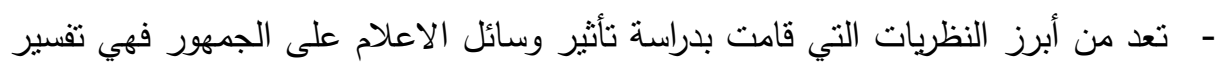

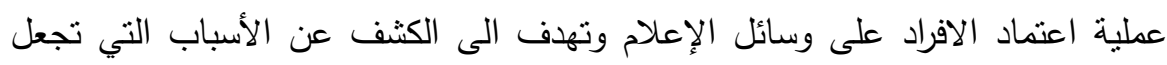

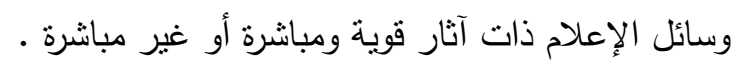
- - تعمل على توضيح الآثار المعرفية والوجدانية والسلوكية لدى المتلقين.

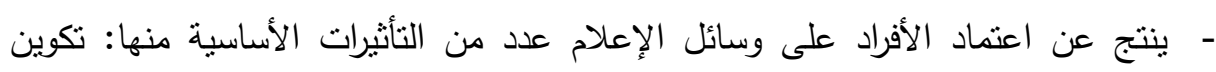

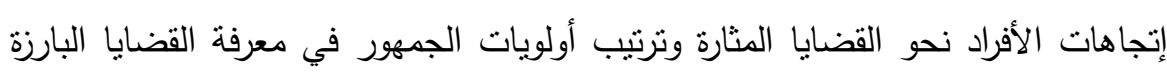

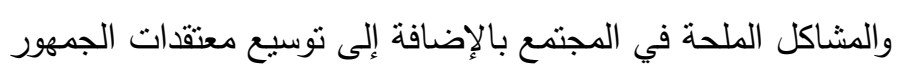
- من خلال النظرية يمكن النعرف على مدى اعتماد الجمهور المصري على بلى وسائل الاعلام

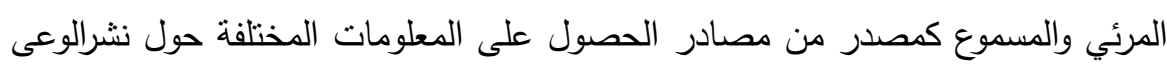

$$
\text { بالتسويق الأخضر موضوع الدراسة. }
$$

نظرية الغرس الثقافى: Cultivation Theory: تهدف نظرية الغرس في الأساس إلى بلى

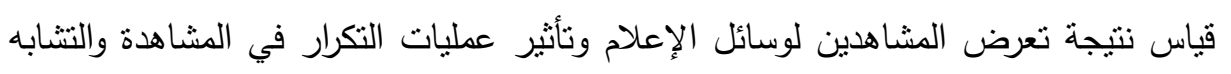

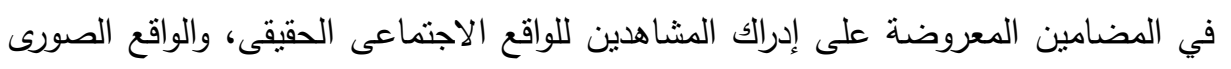
الذى يقدمه الإعلام ووسائله ( G. Gerbner,1976) ويرى الباحثون أن نظرية الغرس الثقافى تعد مدخلاً نظرياً ملائماً لهذه الدراسة وذلك

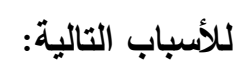
- تعد هذه النظرية هى الأنسب كإطار نظرى للاراسة، نظراً لإهتمامها بتأثيرات وسائل الإعلام ومنها الحملات الإعلانية في تكوين الوعى للمنتج الأخضروالتفاعل معه.

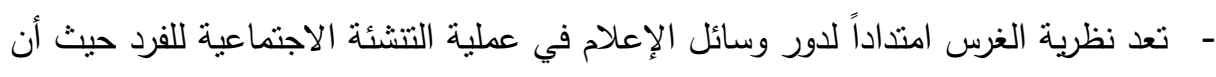
كلاً منهما، عملية تعلم وتعليم، تقوم على التفاعل نتيجة التعرض المستمر والمتزايد.

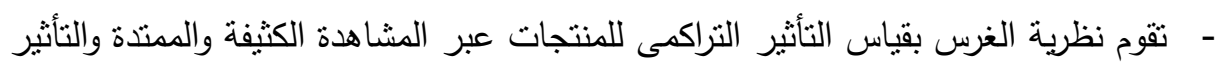
طويل الأجل للمنتج، مما يشكل معرفة واضحة ثم تكوين الإتجاه الذى يسهل عملية

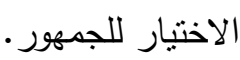


- تعمل نظرية الغرس من خلا التعرض المستمر للحملات الإعلانية من التأثير على

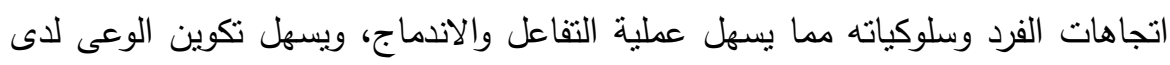
الجمهور بإيجابيات استخدام المنتج الأخضر •

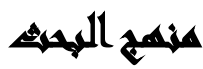

المنهج الوصفي: وقد استخدم الباحثون منهج المسح بإعتباره نموذجاً معياريا لخطوات جمع البيانات والمعلومات عن اعلانات التسويق الأخضرالتى تعرض في وسائل الاعلام الثقليدية والجديدة بهدف تتمية الوعى لدى الجمهور المصرى بالموضوعات البيئية من خلال :

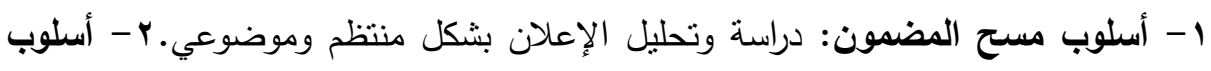
مسح الجمهور: حيث تعتمد الدراسة الميدانية على هذا الأسلوب للتعرف على القى انعكاس مشاهدة الإعلان البيئي على الجمهور ووعيه بالموضوعات البيئية فى مضمونها.

\section{هضوت المهنه}

التزم البحث بالحدود التالية:

ا ـ الحدود البشرية: تتمنل عينة الدراسة الميدانية في عينة عمدية من الجمهور المدصري فى (محافظة القاهرة والجيزة وضواحى الجيزة والقليوبية) اللذين شاهدوا إعلانات التلفزيون ويتعاملوا مع شبكة الانترنت

r. الحدود المكانية: إعلانات المنتجات الصديقة للبيئية المعروضة بالتلفزيون والموجودة على صفحة الثركات النالية على الانترنت وهي: (شركة يونيون اير - شركة العربيشركة فينوس- شركة جيلسي - شركة فلورا- شركة حديد المصريين) ولقد وقع اختيار الباحثون على التلفزيون وصفحات الثركات على الانترنت كونها تمنل الإعلام المصري المحلي الموجه للمواطن المصري داخل حدود الدولة المصرية، وتتناسب اهدافها مع الهن الاهداف الوطنية للمصريين ووجدت اساسا لتدعيم الدور الوطني للدولة. 
r. الحدود الزمانية: الإعلانات المعروضة فى وسائل الإعلام خلال شهر رمضان وعلى

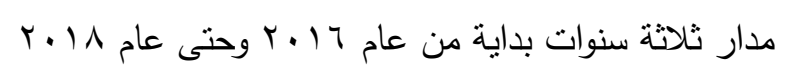

أسإl

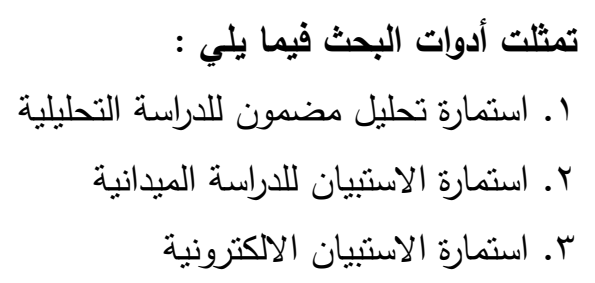

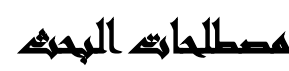

1. تعريف دور وسائل الاعلام: وظيفة التلفزيون والانترنت فى خلق ونشر الوعي البيئي المستدام لدى الجمهور المصري من جراء مشاهدتهم لإعلانات المعروضة على التليفزيون واستخدامهم المنواصل للإنترنت للتعرف على البيئة ومشكلاتها وقضاياها المطروحة. لإندان. r. الوعى البيئى للمستهلك: مدى ادرالك المستهلك لمشاكل البيئة ولأهمية الدور الذى يلعبه كمستهلك فى حمايتها والحفاظ عليها واستعداده لتغيير بعض سلوكياته الثرائية والاستهلاكية لتحقيق ذلك. r. التسويق الاخضر: التسويق البيئي للإعلانات التى تعرض منتجات تجارية وتتضمن

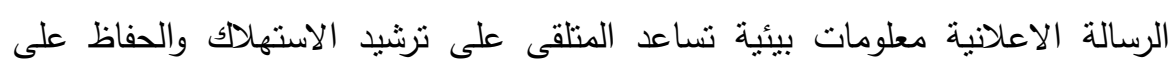

$$
\text { البيئة. }
$$

ء. المنتجات الخضراء: هى جميع المنتجات التى تلبي حاجات المستهلك وتحقق له المنفعة المطلوبة دون الحاق أى ضرر بالبيئة ويتحقق فى انتاجها الإستغلال الأمثل للموارد والطاقة. ه. الجمهور الأخضر: هو الجمهور الأخضر بشكل عام صاحب قرار الثراء الذي يتجنب المنتجات المضرة وغير الودية بيئيا ويسعى للمنتجات الودية بيئيا.

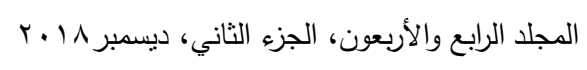


I. الفيسبوك: هو موقع الكتروني يسمح لمستخدميه وهم الجمهور المصري حسب هذا البحث بالتواصل فيما بينهم ومع غيرهم ليتبادلون أفكارهم وآرائهم حول المنتجات الصديقة للبيئة التى تتتجها الثركات والمعلن عنها على صفحات الفيسبوك الخاصة بها.

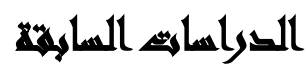

\section{المحور الأول: الاراسات المتعلقة بوسائل الإعلام فى التوعية البيئية}

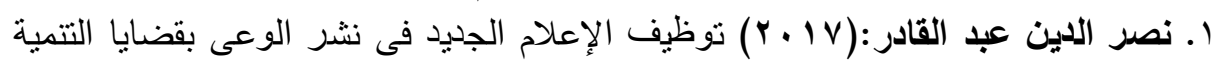

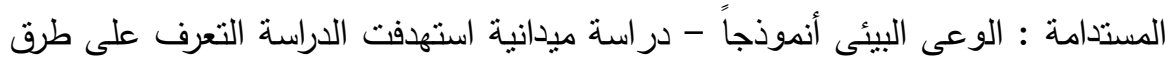

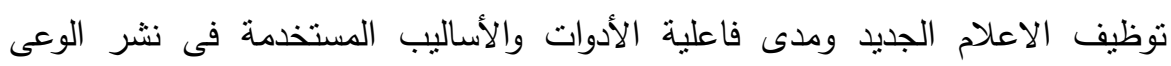

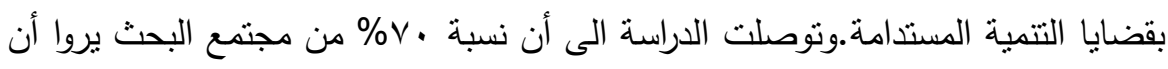
الاعلام الجديد مقصر فى نشر الوعي بالمشكلات البيئية وأن المؤسسات البيئية لم تهنم بالاعلام الجديد كما يجب.

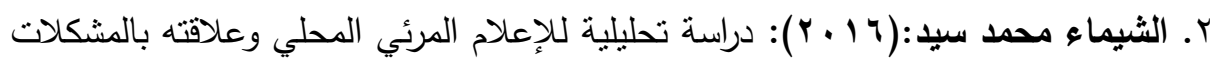
البيئية الزراعية في محافظة الجيزة استهدفت الدراسة التعرف على دور البرامج التليفزيونية التي تبنها القناة الثالثة كبرامج متخصصة في معالجة المشكلات البيئية عامة والمشكلات التئل البيئية الريفية خاصة.وتوصلت الدراسة الى نصيب محافظة الجيزة والقليوبية فى برنامجي

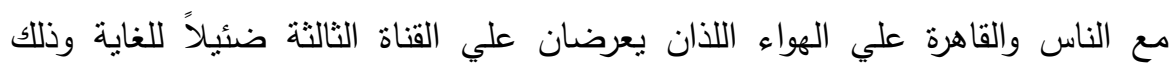
بالمقارنة بمحافظة القاهرة باعتبارها عاصمة الجمهورية ولسهولة الوصول والتواصل معهاء

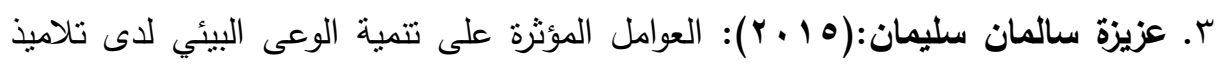

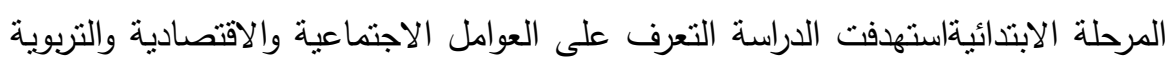

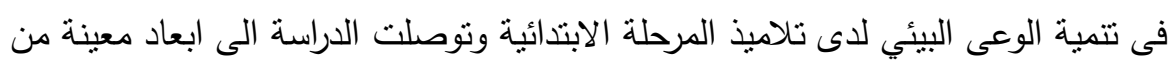

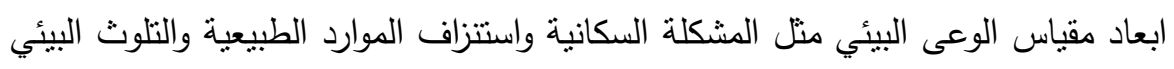

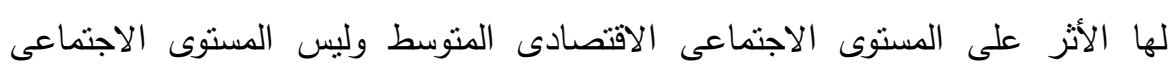
الاقتصادى المنخفض او المرتفع. 


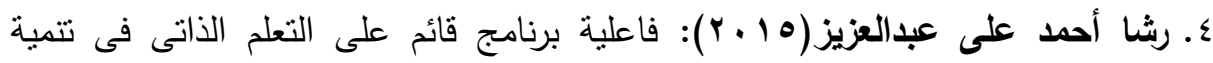
الوعى بالتشريعات البيئية لدى طلاب الجامعات استهدفت الدراسة فياس فاعلية البرنامج المقترح فى رفع الوعى بالتشريعات البيئية لاى طلاب الجامعات وقد استخدمت الباحثة

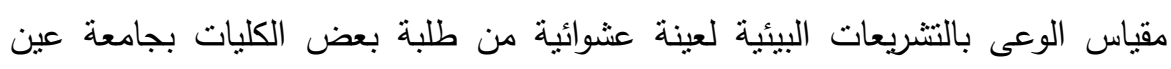

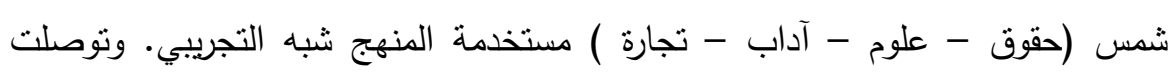

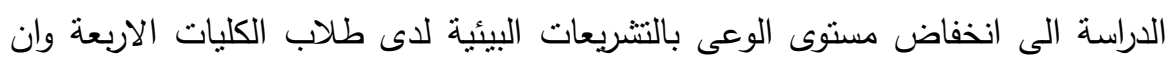

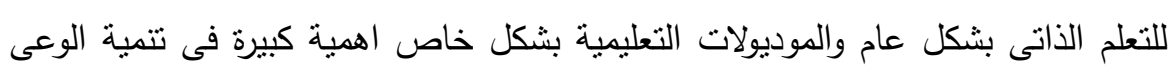

$$
\text { بالتشريعات البيئية لدى طلاب الجامعات. }
$$

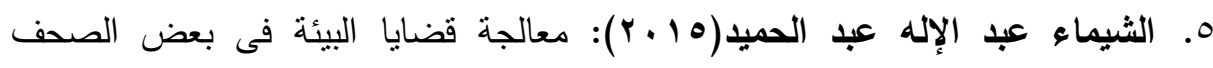

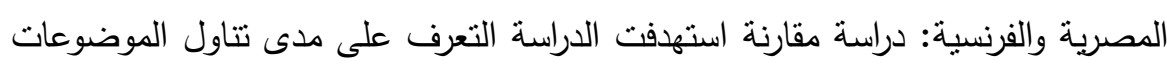

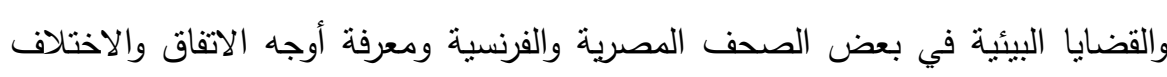
بينها من خلال المقارنة وتحليل المحتوى.وتوصلت الدراسة الى وجود اختلافات دالة احصائياً بالمشكلات البيئية المعروضة في الجرائد المصرية مقارنة بالمشكلات البيئية

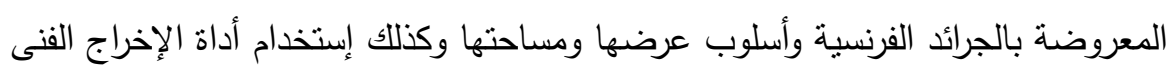
(الصورة) لصالح الصحف الفرنسية.

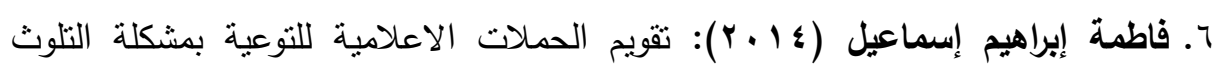

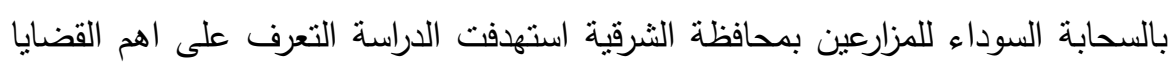

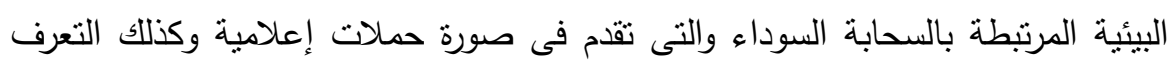
على مضمون الحملة ومدى فاعليتها واسباب متابعة الجمهور لها وقد استخدمت الباحثة منهج المسح بالعينة مستخدمة عينة عشوائية من ابناء محافظة الثرقية من خلال استخدام

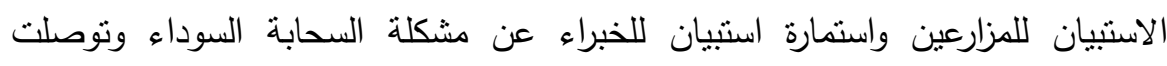

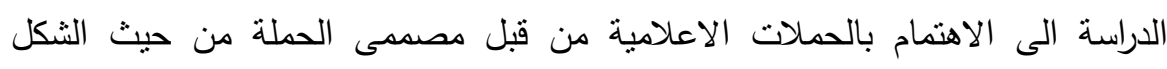

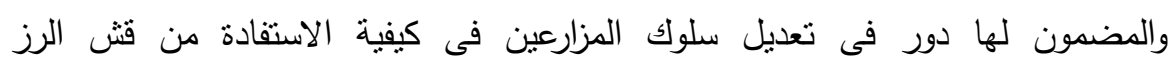
والمخلفات الزراعية الاخرى. 
V. محمد عبد المحسن عطوة وهبة (Y Y Y): نقويم حملة التوعية البيئية لمشكلة انفلونزا الطيور فى محافظة المنوفية استهدفت الدراسة التعرف على انسب الوسائل الاعلامية

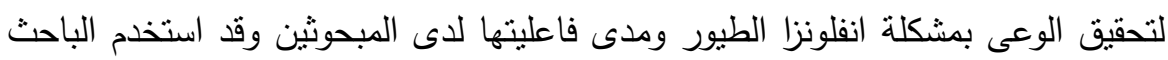
منهج المسح ومنهج المسح المقارن من خلال استخدام الاستنيان ومقياس الوعى البئئي

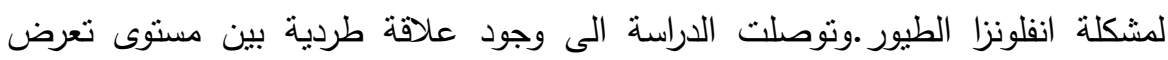
المبحوثين لحملات التوعية البيئية ودرجة الوعى البيئي لديهم.

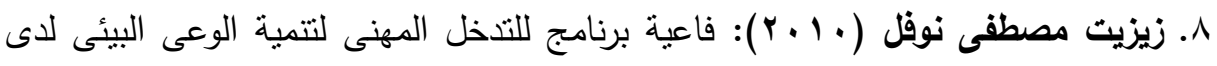

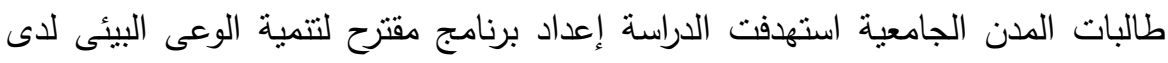
طالبات المدن الجامعية من خلال قياس معرفة وادراك مظاهر التلوث البيئي والاثار المترتبة عليه وكيفية مواجهة المشكلات البيئية وقد استخدمت الباحثة منهج البهن المستح

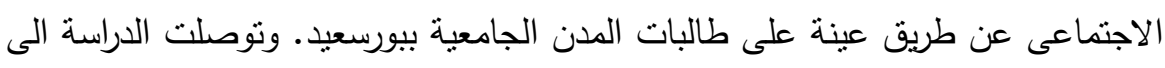
انخفاض فى معدل الوعى البيئي لدى طالبات المدن الجامعية.

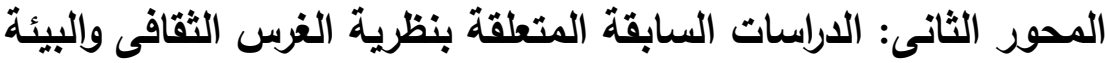

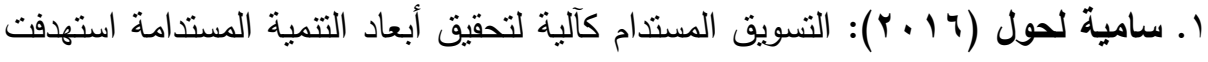
الدراسة إبراز دور التسويق المستدام في تحقيق أبعاد التتمية المستدامة (البيئي، الاقتصادي البهائ والاجتماعي) من خلال تبني مفاهيمه التي تمنل المسؤولية الاجتماعية.وتوصلت الدراسة إلى وجود علاقة تضمينية ما بين التسويق المستدام وأبعاد التتمية المستدامة، إذ يساهم التسويق المستدام في غرس الاعتبارات البيئية لدى الأفراد ومن خلال تبني الثركات

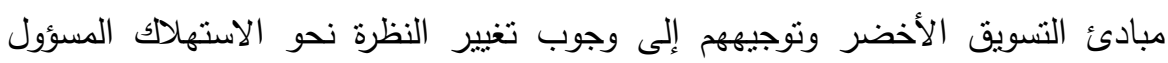
والاهتمام بالتكاليف الاجتماعية. كما يساهم في البعد الاقتصادي بصورة فعالة من خلال

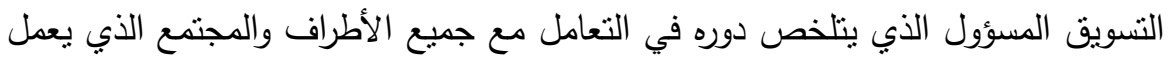
في وسطه والبيئة بشكل مسؤول مبني على أسس أخلاقية ومبادئ وشفافية.

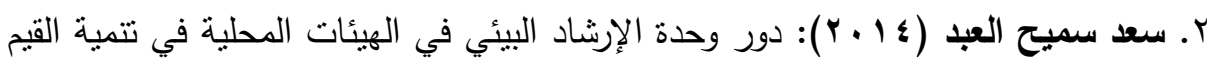
البيئية بمحافظات غزة استهدفت الدراسة التعرف على الدور الذي تضطلع به وحدة الإرشاد

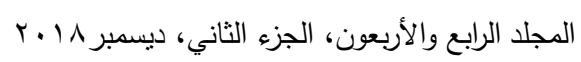


البيئي في نشر الوعي وتتمية الاتجاهات والقيم البيئية المرغوبة لدى أفراد المجتمع المحلي وتحقيق التتمية المستدامة.وتوصلت الدراسة إلى ضرورة استخدام الأساليب التي تراعي

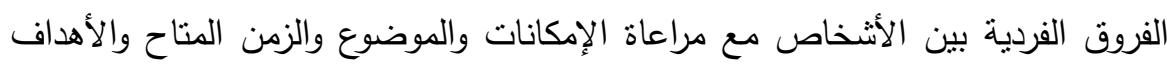

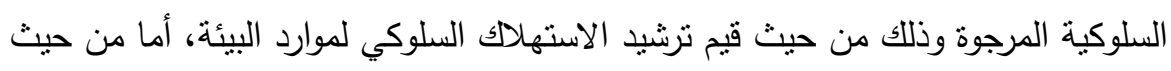

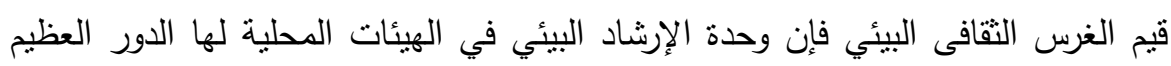

$$
\text { فى توجيه المواطنين لتعديل سلوكياتهم المضرة. }
$$

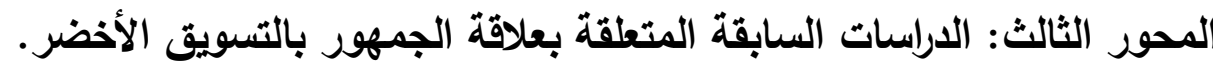

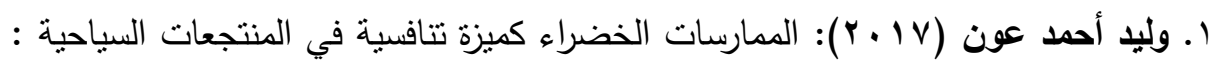
دراسة تطبيقية علي مدينة شرم الثيخ استهدفت الدراسة إلي التعرف علي أثر تطبيق الممارسات البيئية الخضراء داخل المنتجعات السياحية بمدينة شرم الثيخ في تحقيق الميزة النتافسية لتلك المؤسسات وذلك من خلال تحديد إلي أي مدي تهنم المنتجعات السياحية بشرم الثيخ بتطبيق الممارسات البيئية الخضراء وكذلك أهم المعوقات التي نواجه تطبيق تللك الممارسات وماهي المقترحات للتغلب عليها من وجهة نظر مسئولي الإدارة البيئية.وتوصلت الدراسة الى اهتمام إدارة المنتجعات السياحية عينة الدراسة بتطبيق الممارسات البيئية الخضراء والمرتبطة بترشيد استهلاك الطاقة، ترشيد استهلاك الدياه وادارة المخلفات علي الترنيب. r. شمس حسن مندور:(Y Y r Y): التسويق الأخضر وأثزه على حركة السياحة كاتجاه تسويقى حديث استهدفت الدراسة إلي التعرف علي أثز تطبيق التسويق الأخضر والابتعاد

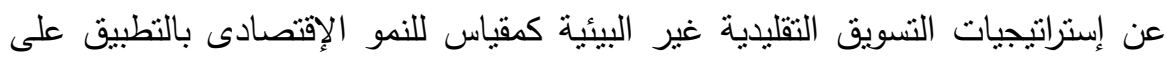
محافظة الفيوم محل الدراسة وتوصلت الدراسة الى أن أكثر المناطق فى إرتفاع معدل

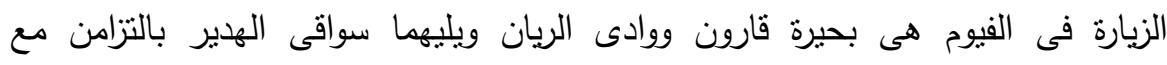

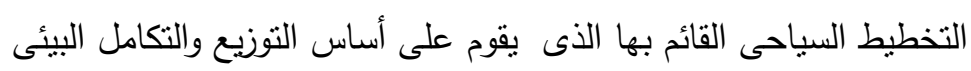

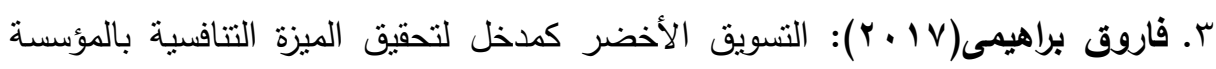

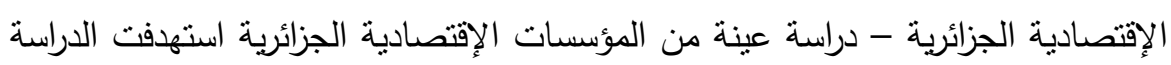
معرفة مدى تأثنر تبني مدخل التسويق الأخضر بمرنكزاته السبعة على تحقيق الميزة 
التنافسية بأبعادها الأربعة في واقع المؤسسة الإقتصادية الجزائرية من خلال الإلمام

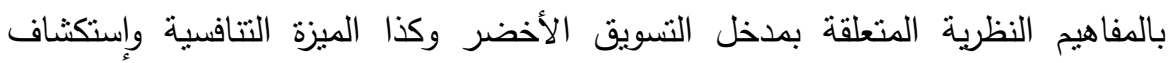
وتحليل مدى تطبيق مدخل التسويق الأخضر في المؤسسات الإقتصادية الجزائرية.وتوصلت الدراسة الى التعرف على الدور الإيجابي لتأثنر تبني المؤسسات

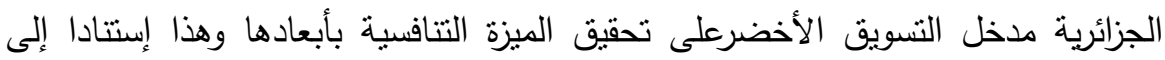
المعلومات المستقاة من تحليل الإسنبيان الموجهة لمسؤولي إم مؤسسة إقتصادية نشطة في السوق الجزائرية.

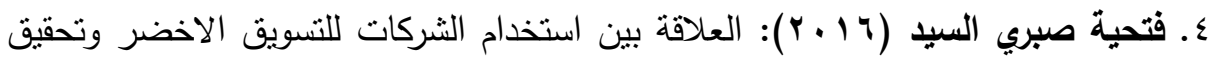
المزايا التتافسية استهدفت الدراسة الى معرفة العلاقة بين استخدام شركات الصناعات الغذائية بمصر للتسويق الاخضر وتحقيقها المزايا النتافسية عن طريق نطبيق منهج دراسة الحالة على ثلاث شركات صناعات غذائية متفاوتة الحجم فمنها كبير الحجم مثل دومتي لمني

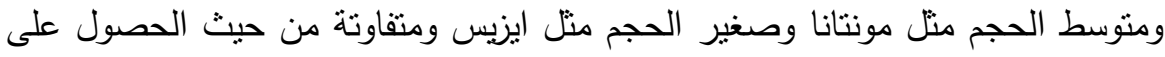

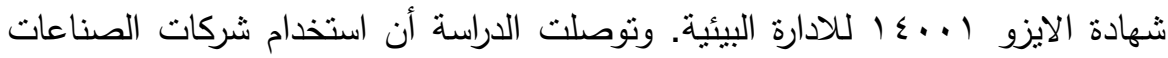
الغذائية للتسويق الأخضر يحقق لها ميزات نتافسية بين الثركات الغذائية المنافسة. 0. صفية قاجة (10) (1) اثر تبني فلسفة التسويق الأخضر في تحسين الأداء البيئي

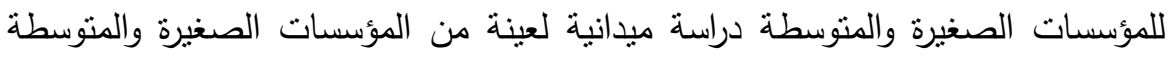
بكل من ولايتي ورقلة وغرداية استهدفت الدراسة إبراز اثر تنبي فلسفة التسويق الأخضر

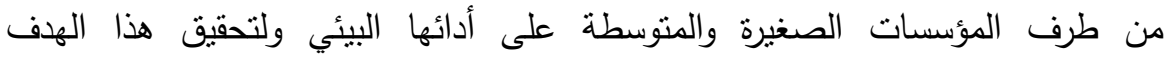
استخدمت الباحثة المنهج الوصفي التحليلي وقامت بتطبيق هذه الدراسة على عينة من

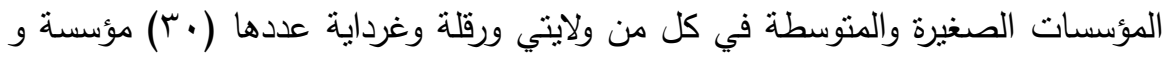

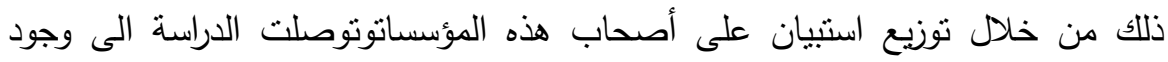
علاقة ذات دلالة إحصائية بين الاتجاهات نحو التسويق الأخضر وانعكاسه على الأداء

$$
\text { البيئي للمؤسسات الصغيرة و المتوسطة داته لهنه }
$$

5. Harpreet Singh Chahal:(2015) Appeals in green advertisingAstudy of factors effecting the persuasiveness of appeals

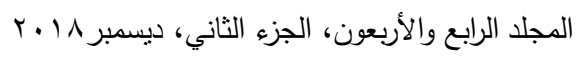


استهدفت الدراسة التعرف على العوامل المختلفة التي تعرقل أو تعزز فعالية إقناع

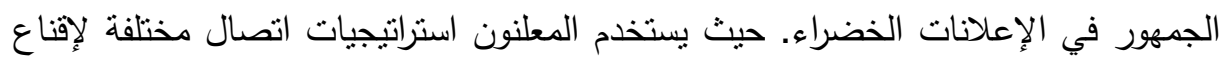
المستهلكين في الإعلان الأخضروتوصلت الدراسة إلى أن ادراك المستهلكين لأهمية القضية

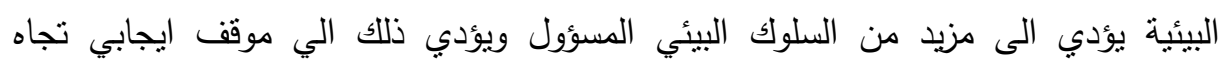

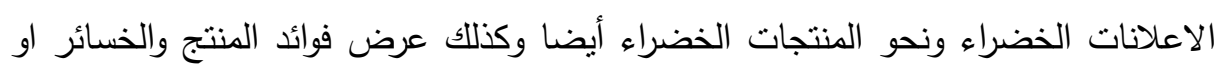
الارباح التي تحقق في المستقبل القريب تؤثر على استجابة المستهلكين.

6. Ahuja Komal:(2015):Study ofgreen Advertising and its impact on consumer purchase intention

استهدفت الدراسة التعرف على العوامل التي تؤثر على موقف المستهلك من الإعلان

الأخضر بما في ذلك الدصداقية، النقة، صورة العلامة التجارية، اختيار وسائل الإعلام

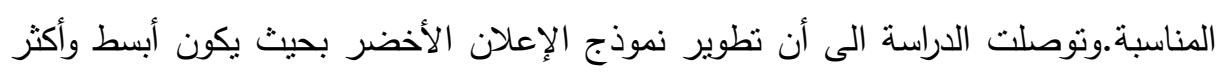
دقة له تأثير ايجابي علي النية الثرائية للمستهلكين.

7. Kadi Sarva:(2015): The influence ofconsumer perception towards greenadvertising on green purchase intention

استهدفت الدراسة دراسة تأثثر تصور المستهلك نحو الإعلان الأخضر وانعكاس ذلك

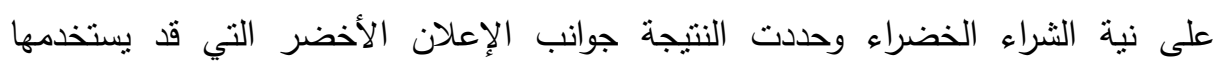
المسوقون أثناء تصميم استراتيجيات الإعلان.وتوصلت الدراسة الى أن لإدراك المستهلكين والمعرفة البيئية وصورة الثركة وتحسين ميزات المنتج ومراعاة الجوانب الأخلاقية تأثثرات

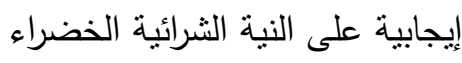
التعليق على الدراسات السابقة ا. هناك اهتمام عالمى بموضوع التسويق الاخضر وتوعية الجمهور بأهميته وفوائده والتى التى التئه تشكل تحديا امام الثركات المنتجة. r. معظم الدراسات التى امكن للباحثة حصرها باللغة الانجليزية وندرة اهتمام الباحثين العرب

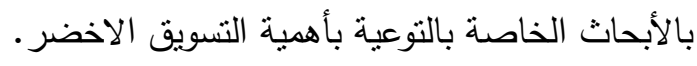


r. أكدت الدراسات على وجود عوامل كثيرة نؤثر على تكوين الاتجاه البيئي نحو التسويق

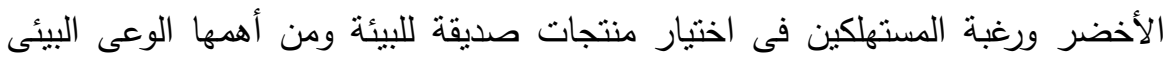
والاهتمام البيئي وكذللك الفئة العمرية والجنسية. ع. اتفقت معظم الدراسات على أن سلوك المستهلك تجاه المنتجات الخضراء ينأثر بدرجة وعيه بالمنتجات الخضراء واهميتها. ه. لم تتطرق اي من الدراسات السابقة الى دراسة دور وسائل الاعلام المختلفة المستخدمة لتوعية الجمهور بالمنتجات الخضراء ويغلب على الدراسات العربية السابقة احصاء تكلفة

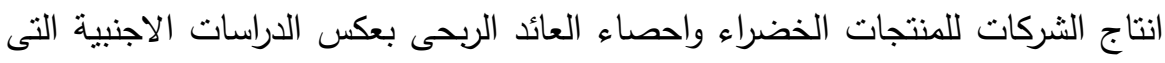
اهتمت بالوعى البيئى للجمهور ، وفى هذه الدراسة حاولت الباحثة ان تنطرق الى معرفة

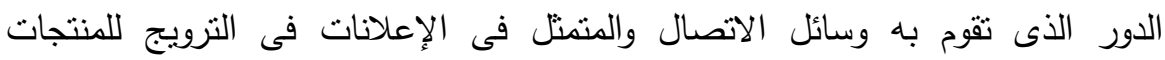
الخضراء 7. افتقار المكتبة العربية لوجود عدد كاف من البحوث فى مجال التسويق الأخضر ويغلب

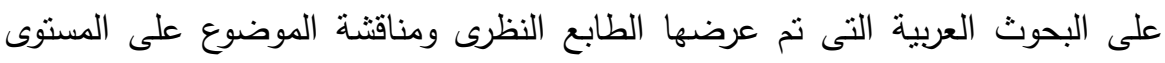

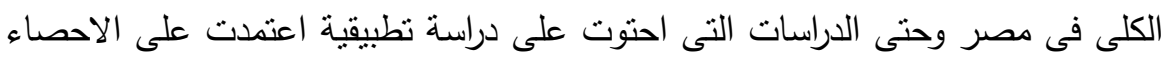
الوصفى فى عرض بعض الظواهر السائدة فى المجتمعات التى درستها تلاك البحوث ولم تتعرض اي دراسة منهم معرفة الدور الذى تقوم به وسائل الاتصال للترويج للمنتجات الخضراء وفى هذا الدراسة تحاول الباحثة سد هذه الفجوة من خلال دراسة دور وسائل

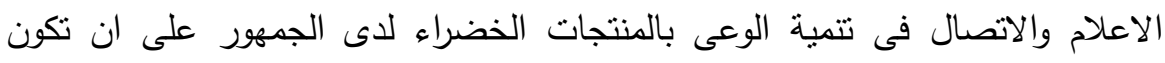
الدراسة إضافة الى الدراسات العربية.

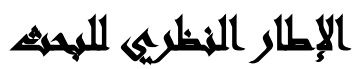

المبحث الاول: وسائل الإعلام: استخدام الجمهور لوسائل الاعلام: يعتبر الدور الأكبر

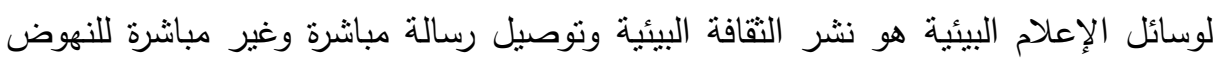
بالمجتمع المصرى والرقي بالوعي البيئي من خلال وسائل الإعلام المختلفة المقروءة

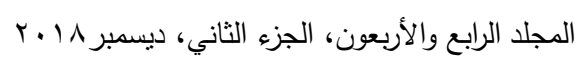


والمسموعة والمرئية وذلك من اجل حماية البيئة والبحث عن سبل الحد من مشكلاتها الحالية،

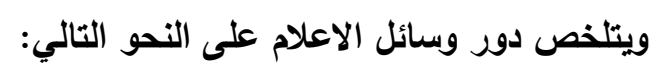

ا. تحديد الهدف: يجب تحديد الاهداف التى يجب إيصالها للجمهور من خلال الرسائل

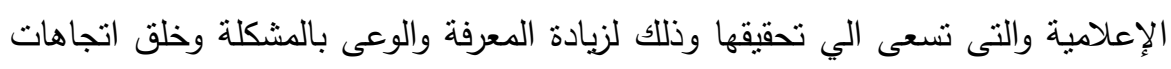

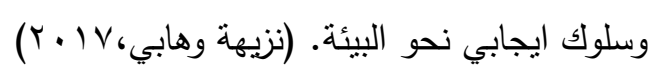

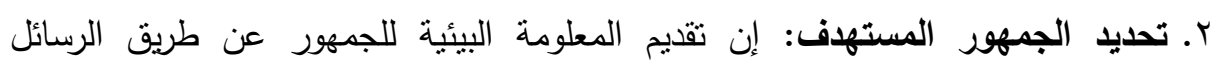

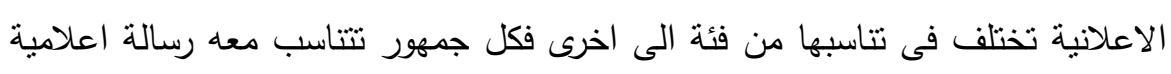
عن طريق وسيلة إعلامية معينة لكى تحقق الهدف المراد الوصول إليه. (عبير تباني،

r. اختيار الوسيلة: لكل فئة من الجمهور وسيلة اعلامية مناسبة له يتلقى فيها الرساله

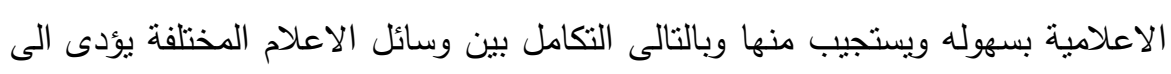
بناء الاتجاهات المطلوبة والوصول الى السلوكيات التى تكفل الحماية البيئية. ( الهام

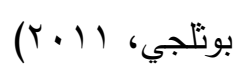

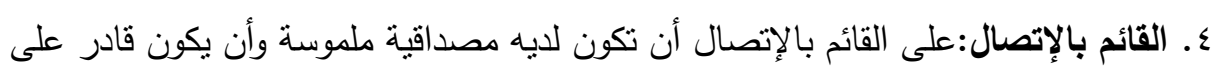

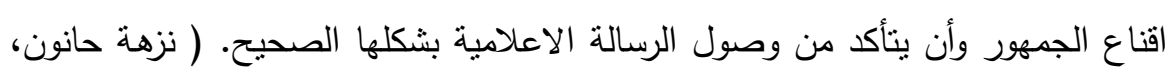

$$
(r+\lambda
$$

ه. المضمون: يجب أن يقدم المضمون بأسلوب مبسط وجذاب وواضح وبعيد عن

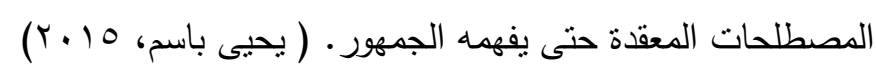

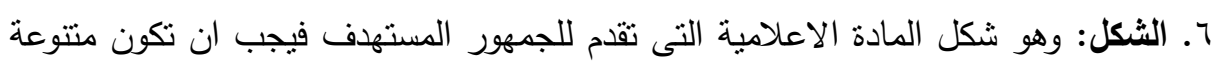
ومستمرة وتخاطب احتباجات الجمهور حتى تجذب انتباهه وبالتالى تسهل عملية الإقناع.

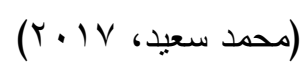

التليفزيون والجانب الاعلاني: تتفرد الاعلانات التلفزيونية بتميزها عن الاعلانات فى الوسائل

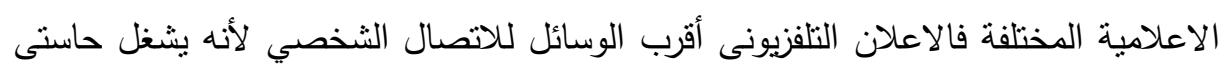

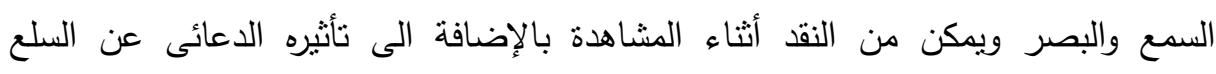


والخدمات المختلفة ثم توليد حالة نفسية تتعدى لغة الكلام أو الصورة الجامدة كما هو الحال

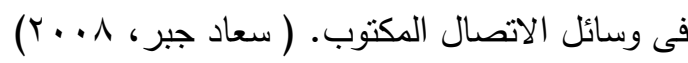

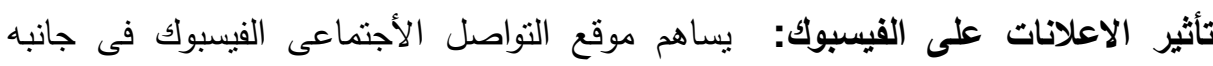

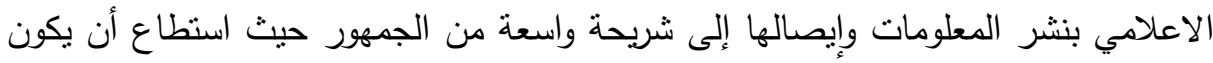

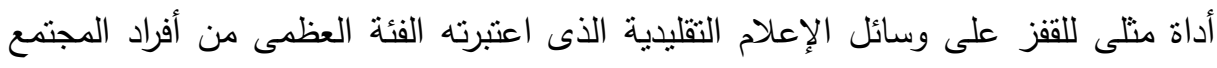
خير من يستطيع القيام بدور هذا الإعلام المنشود المبحث الثانى: الوعي البيئي: دور وسائل الإعلام فى تتمية الوعى البيئى: تتبع أهمية الإعلام من خلال الدور الكبير الذي يقدمه من خلال وسائل الاعلام في مجال الثقافة والتربية والبيئة لكافة أفراد المجتمع مما فسح المجال للتعرف على الإعلام البيئي ودوره من خلال

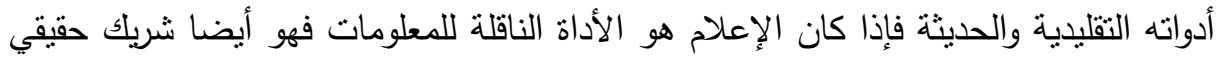
في التوعية البيئية. ويتلخص دور الاعلام فى تنمية الوعي البيئي فى الآتى:

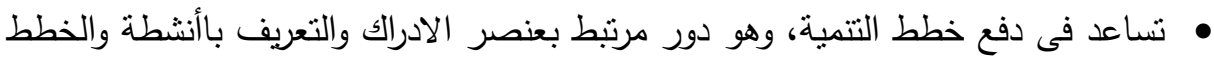
التتموية. • للاعلام دور اساسي فى التتشئة الاجتماعية للأفراد والتربية السلوكية لهم تجاه قضايا معينة وخاصة القضية البيئية التى ترتبط بالسلوكيات.

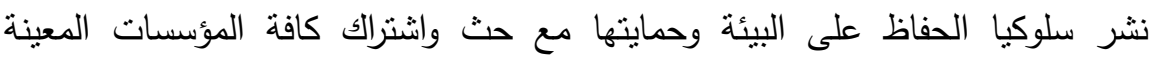
للاهنمام بقضايا البيئة ومعالجتها. المبحث الثالث: الاعلان الأهداف النفسية للإعلان: ان الرسالة الاعلانية هي مجموع المعلومات التقصيلية والكافية

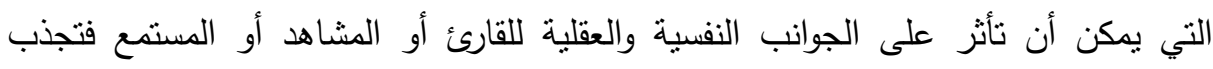
انتباههم وتثير اهتمامهم ثم تخلق الرغبة لديهم لافتتاء السلعة او الخدمة والتجاوب مع فكرة

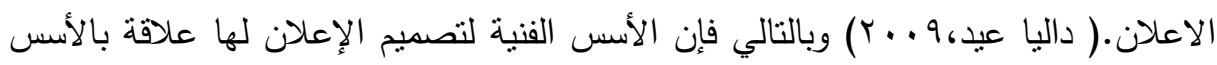

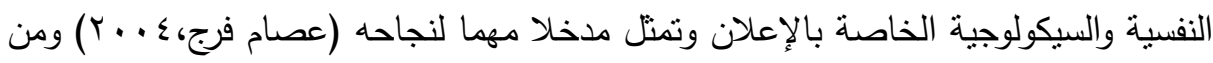
العوامل التي نساعد على نجاح أثز الرسالة الاعلانية :

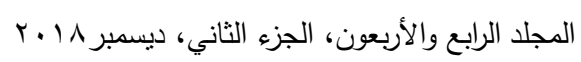




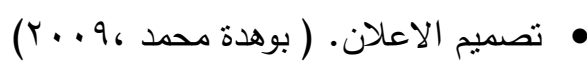

• التكرار حيث ان فرص تذكر اعلان شوهد لمرة واحدة فقط ضئيلة جدا، لذا يلجأ المسوق الى الرفع من هذا الاحتمال وبالتالي الرفع من احتمال الاستجابة للاعلان.

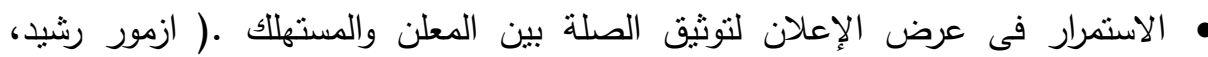

• الوقت المناسب لإذاعة الاعلان أب منح الاعلان الوقت الكافي للتغلغل في ذهن المستهلك

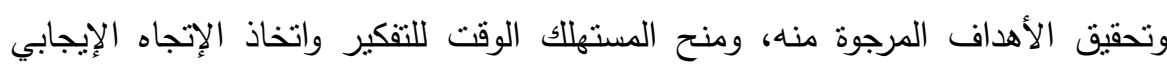

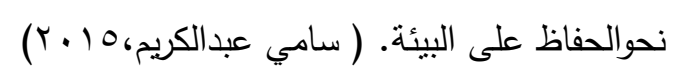

المبحث الرابع : التسويق الاخضر

مفهوم التسويق الأخضر: لقد أثثار مفهوم التسويق الأخضر منذ عرف وحتى الآن العديد من

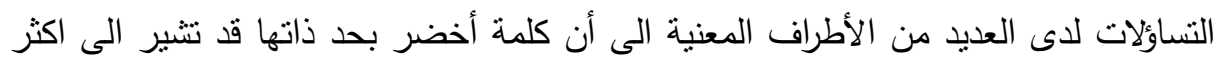

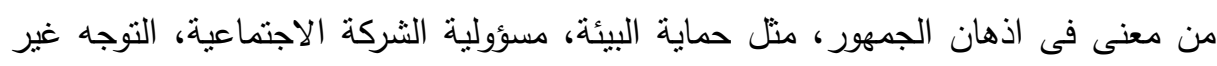
الهادف للربحية وحماية المستهلك، وحتى فى اوساط العاملين فى مجال التسويق فإن مفهوم

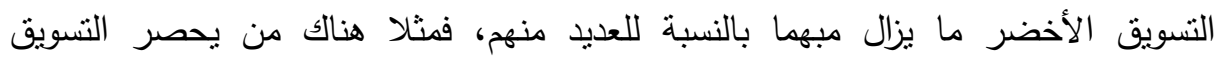
الأخضر فى أنشطة اعادة التدوير Recycling فقط او المساهمة فى الانثطة الاجتماعية

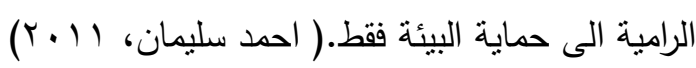

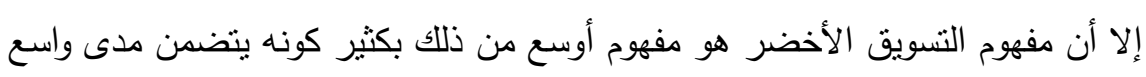

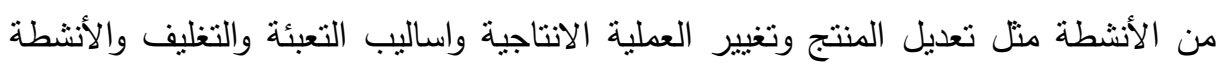
التوزيعية وفى الوقت نفسه فإن مدخل التسويق الأخضر ليس حكرا على مجال معين وانما

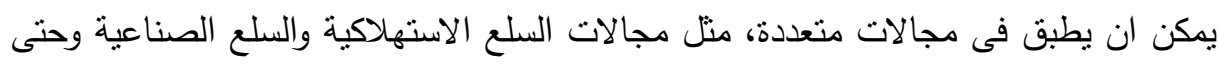

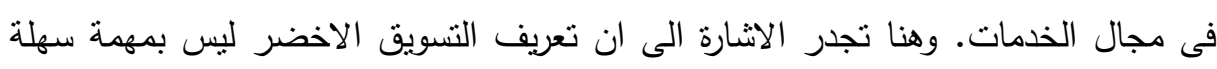
وأنه لايوجد حتى الآن تعريف متفق عليه عالميا، فقد تباينت التعريف من مرحلة لأخرى فمثنا عرفت جمعية التسويق الأمريكية (A.M.A) التسويق الأخضر على أنه عملية علية دراسة النواحى الايجابية والسلبية للأنشطة التسويقية. 
وبالتالى يصل الباحثون الى تعريف التسويق الأخضر على حسب هذه الدراسة أنه " الإعلانات التى تعرض منتجات تجارية والتى يتم التسويق لها بيئيا وتتضمن الرسالة الاعلانية الإنية معلومات بيئية نساعد المتلقى على ترشيد الاستهلاك والحفاظ على البيئة

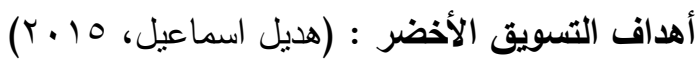
1. إلغاء مفهوم النفابات أو تقلبيلها: لقد تغير المفهوم التقليدي في التعامل مع النفايات وبقايا الصناعة ضمن التسويق الأخضر، حيث أصبح التركيز على تصميم وإنتاج سلع بدون نفايات بدلاً من كيفية التخلص منها، وذللك من خلال رفع كفاءة العمليات الإنتاجية .

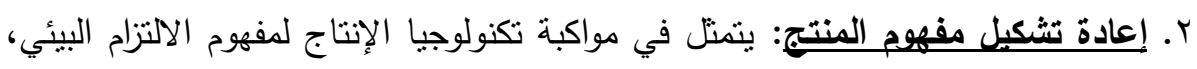

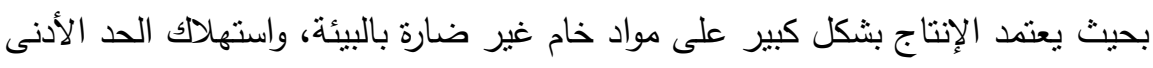

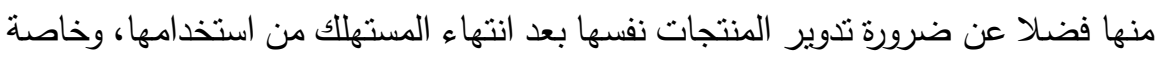

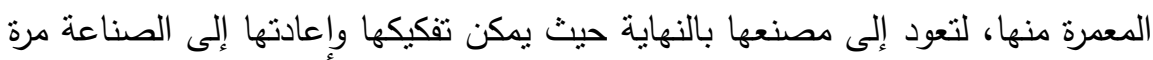
أخرى ضمن حلقة مغلقة. أما التغليف، فيعتمد على مواد خام صديقة للبيئة وقابلة للتدوير . r. وضوح العلاقة بين السعر والتكلفة: يجب أن يعكس سعر المنتج تكلفته الحقيقية أو يكون

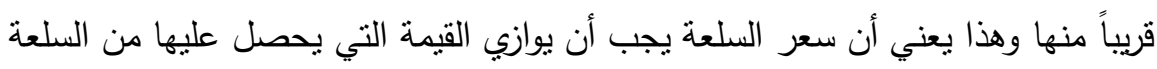

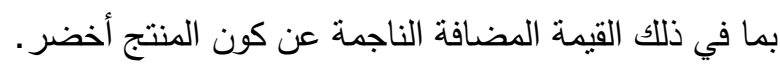

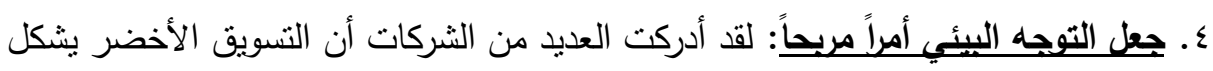

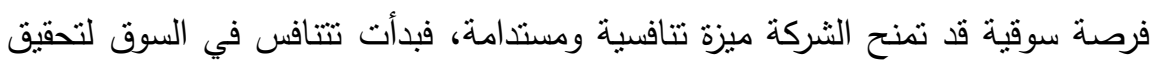
الكسب السريع، بغض النظر عن الآثار السلبية على البيئة

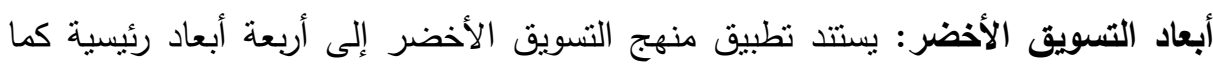
يلي: ا ـ تقليل التلف والضياع: إن التلوث أو تقديم منتجات تالفة أو غير ملاءمة للاستعمال عادة

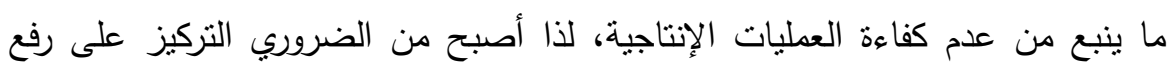
كفاءة هذه العمليات عوضا عن البحث في كيفية التخلص من نلك المنتجات التالفة، أو مخلفاتها الصناعية.

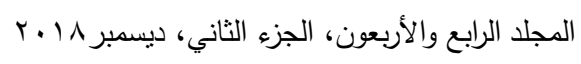


r. توضيح العلاقة بين الكلفة والسعر : إن كل منتج يجب أن يعكس كلفته الحقيقية أو ما يقاربها عند تحديد السعر الخاص به، وهذا يعني أن سعر السلعة يجب أن يوازي القيمة

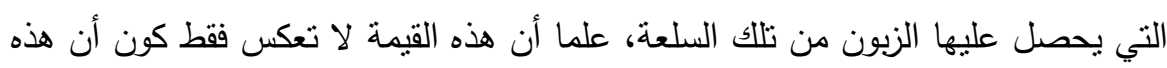

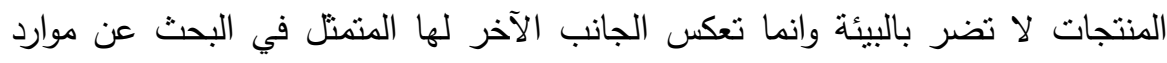
بديلة وحماية الموارد الطبيعية وما يحتويه ذللك من كلف عالية كارتفاع مصاريف البحث والتطوير • بلاله وحمانه r. جعل التوجه البيئي أمرا مربحا: لقد أدركت العديد من المنظمات أن التسويق الأخضر

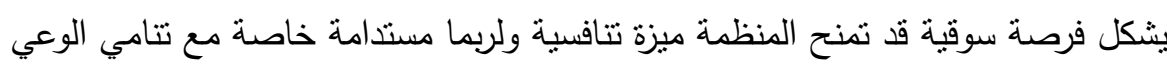
البيئي بين المستهلكين وتحولهم التدريجي إلى مستهلكين خضر وبالتالي سيكون هذا التوجه

$$
\text { أمرا مربحا وخاصة في المدى الطويل. }
$$

ع. تغيير المفاهيم المتعلقة بالمنتجات: تتمثل في أن المنتجات الجديدة يجب أن أن تعتمد بشكل

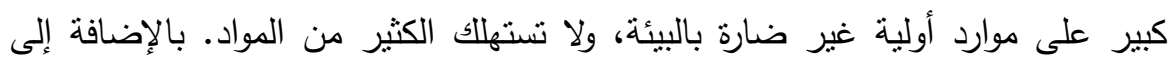

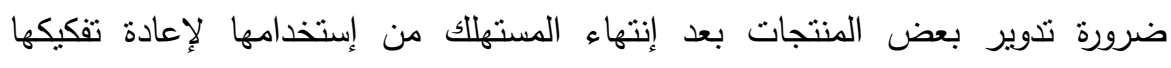
والإستفادة منها مرة أخرى، فضلا عن ضرورة تغيير أساليب تعبئة وتغليف المنتجات بحيث

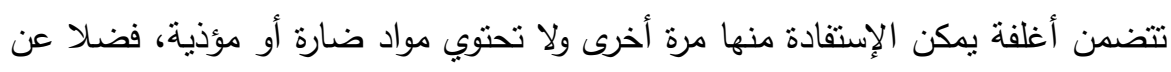
الإعتماد على مصادر بديلة لتصنيع تلك الأغلفة.

\section{الإجبراعاهي المنهيجة للهمهث}

مجتمع الاراسة: يتمتل مجتمع الدراسة الميدانية من عينة عمدية قوامها . .ـ مفردة من

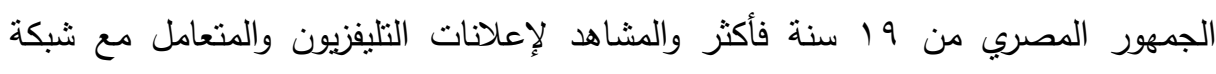
الانترنت، أما مجتمع الدراسة التحليلية فيمثل اعلانات المنتجات الصديقة للبيئة بالتليفزيون والموجودة على صفحة الثركات التالية وهى : (شركة يونيون اير - شركة العربي- شركة الثرنة فينوس- شركة جيلسي - شركة فلورا- شركة حديد المصريين) 
أولا: قام الباحثون بتصيم صحيفة استبيان تضمنت أسئلة لتنطية الأهداف الرئيسية من

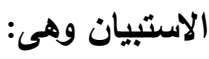

- الييانات الأولية: وشملت ( السن - النوع - مسنوى التعليم - المستوى الاقتصادى )

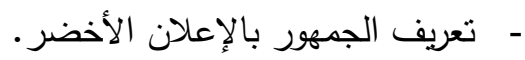

- أى وسائل الاعلام المفضلة للجمهور عند متابعة إعلانات التسويق الأخضر

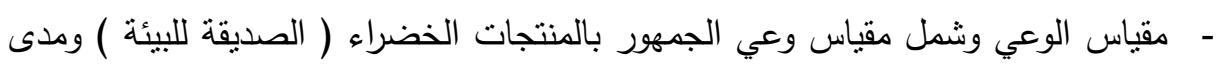
وعيهم بالهدف من الاعلان وارتباطه بحياتهم اليومية. - - مقياس الإتجاه نحو اعلانات النسويق الأخضر من خلال مجموعة الإندان من الأسئلة لقياس

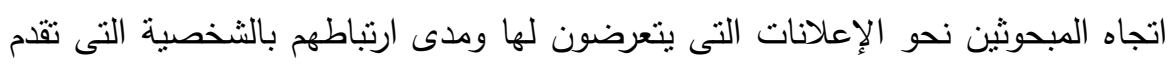

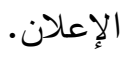

- مقياس لتحديد السلوك من خلال عدة أسئلة لتحديد رد فعل الجمهور من نلك الإعلانات. ثانيا: استمارة تحليل مضمون للاراسة التحليلية: قام الباحثون بتصميم استمارة تحليل

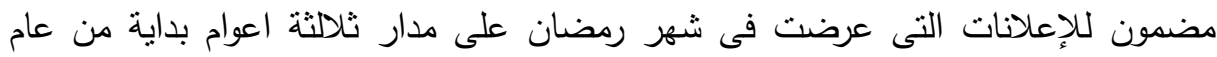

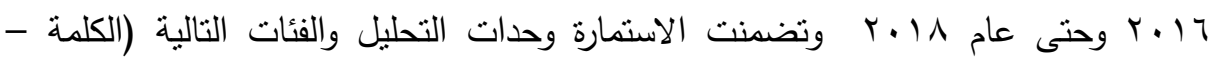

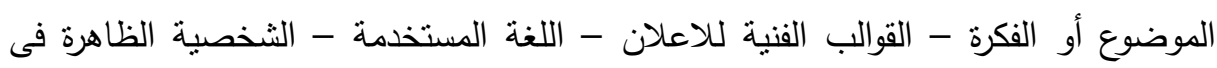

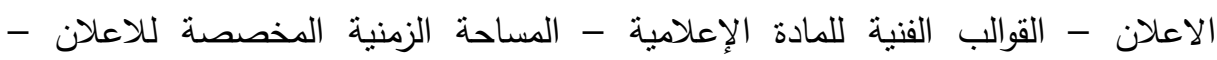

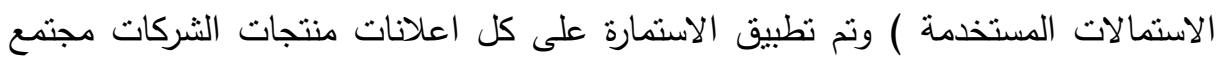

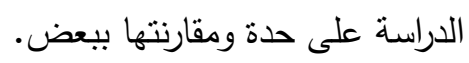
وتعكس نلك الإعلانات أهمية ترشيد استخدام الإعلان التلفزيوني واعلانات الانترنت

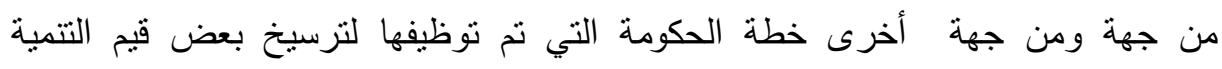
الستثامة والحفاظ على البيئة بما يتفق مع السياسات العامة المتعلقة بالتتمية والوعي البيئي لئي و التي تعمل من شأنها الدولة. 


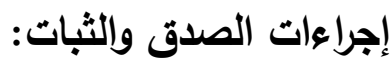

• الصدق الظاهري: قام الباحثون بإعداد الصورة الأولية لعبارات الاستيان لبيان مدى قدرة كل عبارة

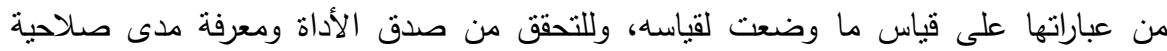

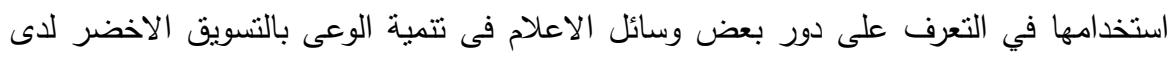
الجمهور المصرى ثم قامت بعرضها على هيئة التحكيم من أساتذة الاعلام وعلم النفس والبيئة وذللك للتأكد من مدى ملائمتها لكل مجتمع وموضوع الدراسة والأساليب الإحصائية كما قامت هيئة التهائة التحكيم بإجراء التعديلات المناسبة ومن ثم إخراج الاستبانة بصورتهائها النهائية. كما تم استخدام معامل ارتباط كل عبارة من العبارات مع المجموع الكلى لعبارات الاستبانة (معامل ارتباط بيرسون) لإصدار الحكم على مدى صلاحية الفقرات وسلامة صياغتها وملاءمنها لموضوع الدراسة. والجدول رقم (1) يوضح معاملات الارتباط لأداة البحث الحالي. جدول( (1): معاملات صدق محاور الدراسه

\begin{tabular}{|c|c|c|}
\hline مستوى & معامله الأكتباط للأستونيان مع & العبـاره \\
\hline 0.000 & $.225 * *$ & أى أنواع الوسائل الإعلامبة التي تتابعهاعند مشاهدتك للإعلانات \\
\hline 0.101 & $.082 \% *$ & متي بدآت تثأهد الإعلانات التلفزيونية للثشركات التألية \\
\hline 0.000 & $.626 * *$ & هل تلتصفح الموقع الإكترونى للثنركات الثالية \\
\hline 0.000 & $.641 * \%$ & متى بدأت تتصفح الموقع الإلكترونى للشتركات التالية \\
\hline 0.000 & $.541 * *$ & 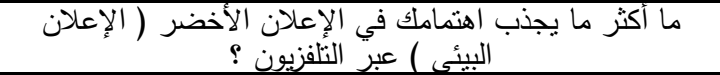 \\
\hline 0.000 & $.517 * *$ & 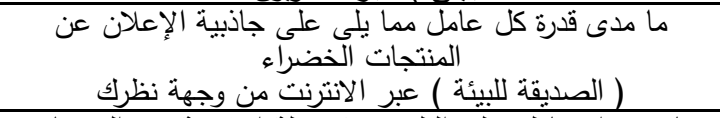 \\
\hline 0.000 & $.409 * *$ & ما مدى اعتمادك على التلفزيون كوسيلة إعلامية عن المنتجات \\
\hline 0.000 & $.616 * *$ & 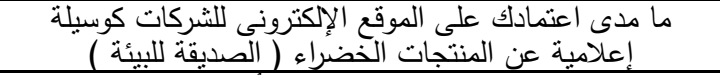 \\
\hline 0.000 & $.192 * *$ & ما رد فعلك بعد تعرضك لإعلان التلفنتج الأخضر ( الصديق للبيئة \\
\hline 0.000 & $.541 * *$ & ما شكل الإعلان الذي تفضله \\
\hline 0.000 & $.392 * *$ & أثناء تعرضك لإعلانات شركة فينوس ما رأيك في العبارات الآتية \\
\hline 0.000 & $.423 * *$ & ما السلوك الذى ثقوم به أثناء تصفيلك للصفحة الرسمية لثركة \\
\hline 0.000 & $.334 * *$ & أثناء مشاهتلك لإعلانات شركة يَّنيون اير ما رأيك فى العبارات \\
\hline 0.000 & $.777 * *$ & ما ذا تفعل أثناء تصفحك لموقع شركةًالعربي على الانترنت \\
\hline 0.000 & $.628^{* *}$ & ما ذا تفعل أثناء تصفحك لموقع شركة فلوراعلى الانترنت \\
\hline 0.000 & $.563 * \%$ & هل تتابع اعلانات شركة حديد الدصريين \\
\hline
\end{tabular}


يوضح الجدول رقم (1) أن جميع معاملات الارتباط بين درجة كل محور والدرجة الكلية

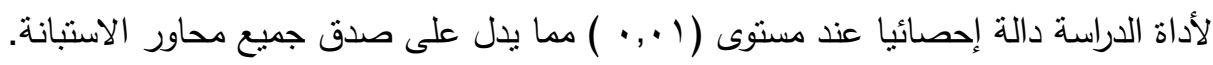

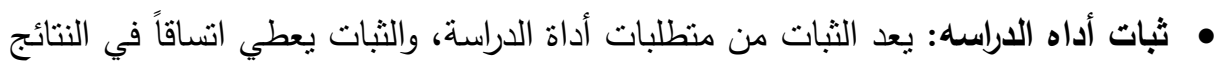

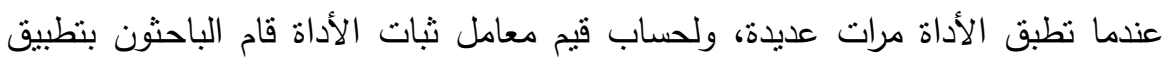

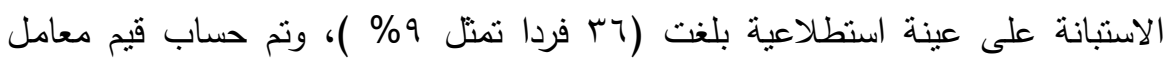
الثبات بطريقة ألفا كرونباخ Cornpach - Alph و باستخدام معامل (الفاكرونباخ)

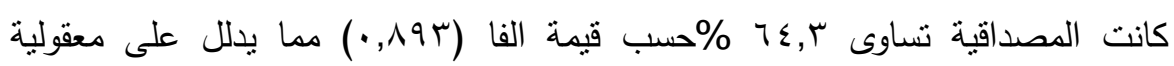

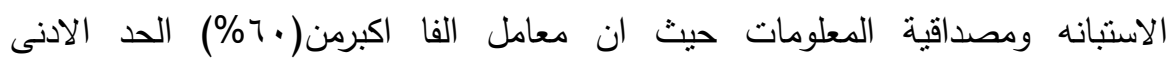
ل ل لمصداقية.

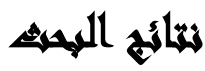

بعد تطبيق الاستمارة الميدانية على الجمهور، وتقريغ الدرجات وادخالها على الحاسب الآلى ومن خلال برنامج (spss)، اوضحت المعالجة الاحصائية النتائج الاتية:

أولا: نتائج البحث التحليلية

جدول رقم(؟): نوزيع عينة الدراسة وفقًا للييانات الاساسية لإعلانات المنتجات الخضراء (اعوام التحليل

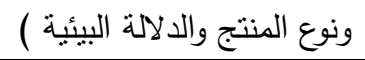

\begin{tabular}{|c|c|c|c|}
\hline الدلالة البيئية & نوع المنتج & الاعوام & الاعلَّبرات \\
\hline 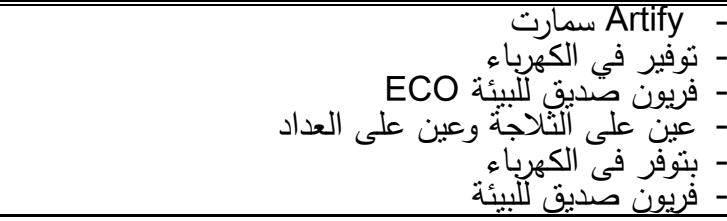 & توبتاجنيف & \multirow{2}{*}{ 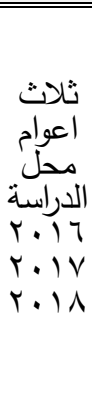 } & يونيون اير شرك \\
\hline 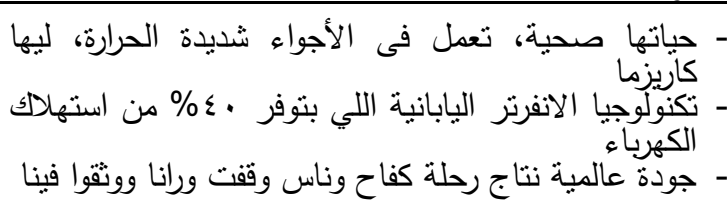 & 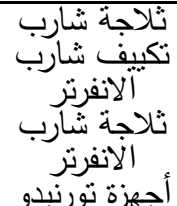 & & العربي \\
\hline
\end{tabular}

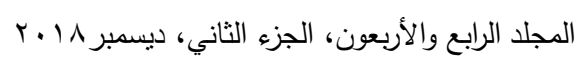


تابع جدول(r)

\begin{tabular}{|c|c|c|c|}
\hline الدلالة البيئية & نوع المنتج & الاعوام & الاعتلانيرات \\
\hline 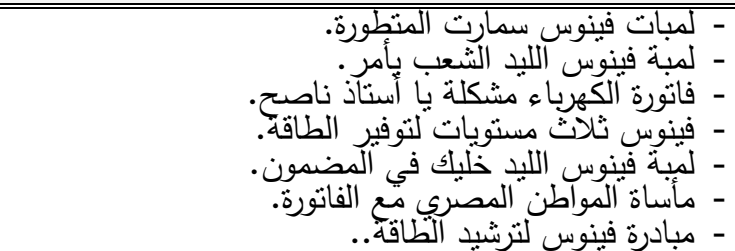 & لمبات & & شينشوسة \\
\hline 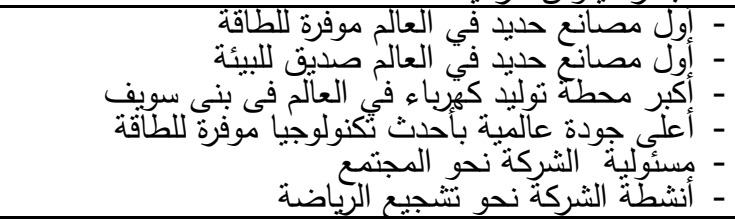 & حديد & & شركيد \\
\hline 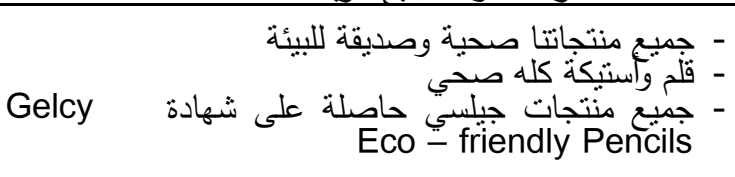 & أقلام خشاصب & & شيلسي \\
\hline 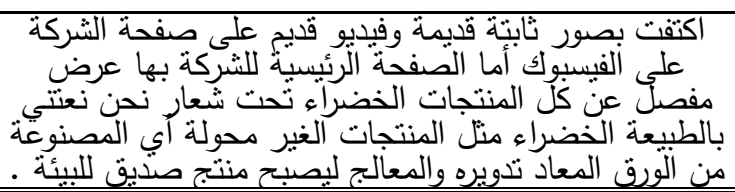 & مناديل ورقية & & شركة فلورا \\
\hline
\end{tabular}

تدل بيانات الجدول السابق على عدة نتائج من أهمها:

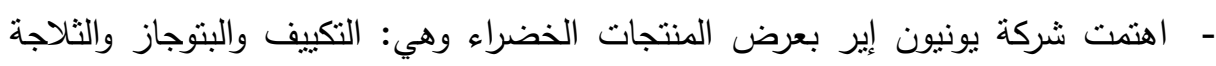

بينما عرضت

- شركة العربي ثلاجة شارب، وثلاجة و تكيف شارب الانفرتر، وأجزة نورنيدو وهي من

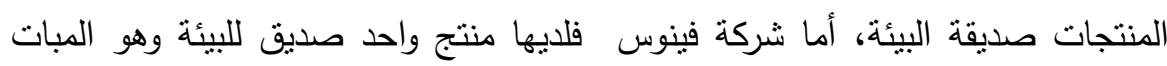

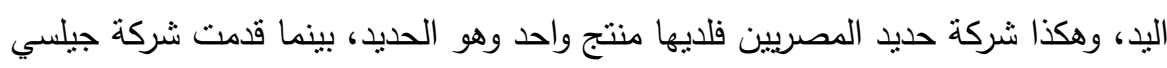

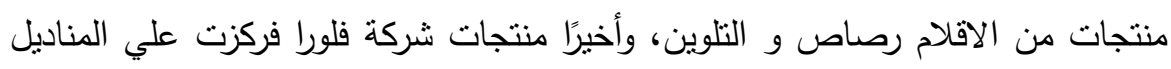

الورقية فقط .

- اهتمت شركة يونيون إير بتقديم المعلومات البيئية الواردة في الإعلان والتى تهم الجمهور

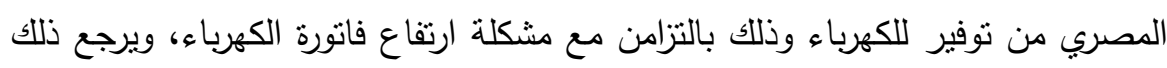
إلى زيدة الأسعار وانخفاض المستوى الإقتصادى للجمهور بينما إهتمت شركة العربي في 
إعلاناتها بالدلالة البيئة فى استخدام الجمل البيئية وتوضيح مواصفات المنتج البيئية

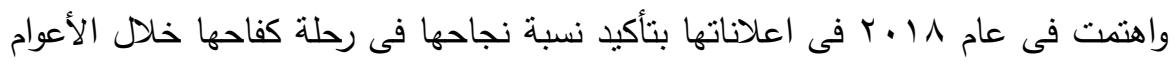

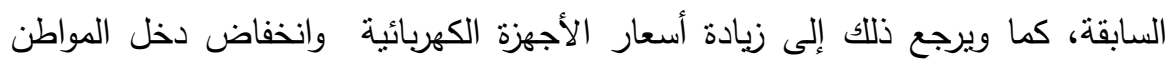
المصري، أما إعلان شركة فينوس أهتم بكلمات ذات دلالة بيئية تؤكد نوفير المنتج

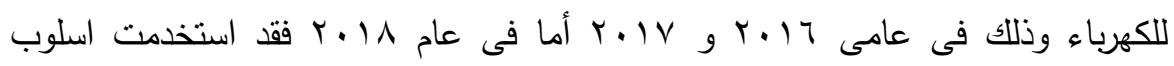
العروض والخصومات على المنتج فى دعم شباب مصر . - جاء إعلانات شركة حديد المصريين بثلاث أعوام محل الدراسة بالاهنمام بتعريف الجمهور

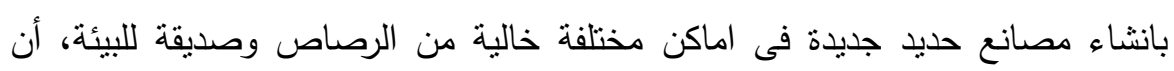

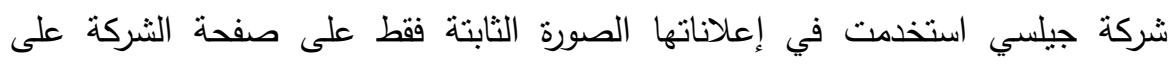
الفيسبوك ولم تلجأ الى الاعلان التليفزيوني وبمعدل كل يومان اعلان ثابت عناصره صورة للمنتج سواء أقلام رصاص أو أقلام تلوين أو أستيكة بالإضافة الى كلمة بيئة مختلفة فى ألى كل اعلان وشعار الشركة الذى يحتوى على كلمة منتجات صديقة للبيئة وهى عناصر غنية عن التعريف والتى تصل الى الجمهور بدون مجهود في شرح الإعلان.

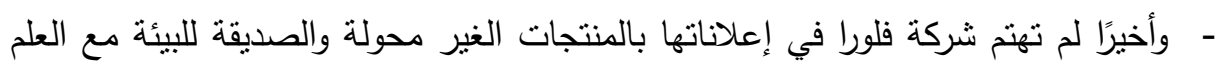
أن مبدأ الشركة تتوع مصادرالطاقة و توفيرها و الحفاظ على البيئة واعتبارها المفتاح لبوابة إندانة

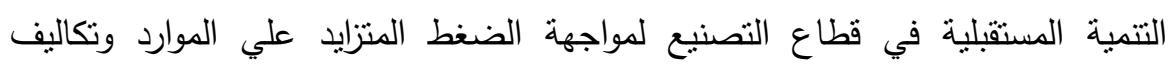
الطاقة، وقد لاحظت الباحثة أن الصفحة الرئيسية لثركة فلورا بها معلومات مفصلة

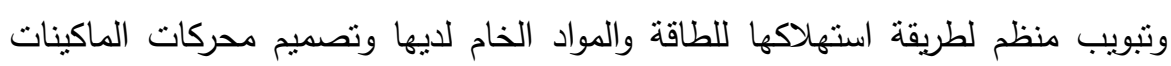
وغيرها ولكنها لم تنتغل ذللك فى تعريف الجمهور بدليل عدد اللايكات والتعليقات القليلة

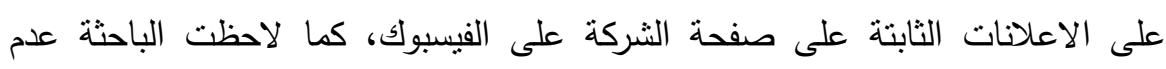
وجود اعلانات تليفزيونية لمنتجات شركة فلورا .

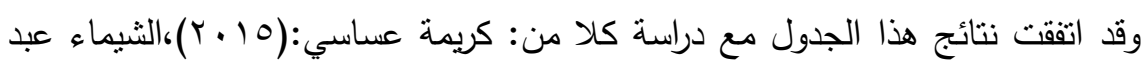

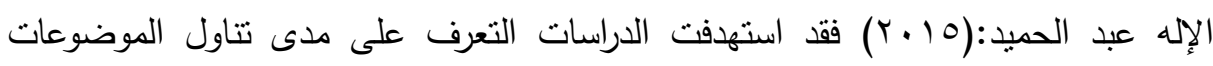

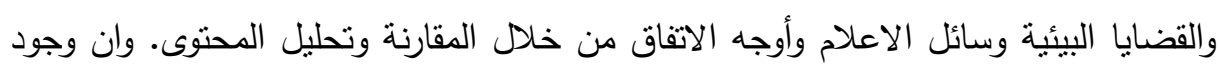

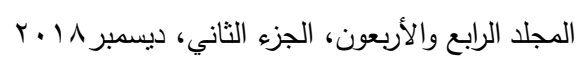


عدد كبير من الاجهزة نراعي الظروف البيئية وتوفر الكهرباء أي انها نراعي المواصفات البيئية الحديثة التى تمهد للحفاظ على البيئة مع استخدام تكنولوجيا متميزة ثانيا: نتائج البحث الميدانية: أهم عناصر جذب المبحوثين لإعلانات المنتجات الخضراء بوسائل الإعلام المختلفة: 1. أكثر ما يجذب اهتمام المبحوثين في الإعلان الأخضر ( الإعلان البيئى ) عبر التلفزيون جدول رقم(؟): توزيع عينة الدراسة طبقاً لأكثر ما يجذب اهتمام المبحوثين في الإعلان الأخضر (الإعلان البيئى) عبر التلفزيون

\begin{tabular}{|c|c|c|c|c|c|c|c|c|}
\hline \multicolumn{2}{|c|}{ الوزن المرجح } & \multicolumn{2}{|c|}{$\bar{y}$} & \multicolumn{2}{|c|}{ أحيانًا } & \multicolumn{2}{|c|}{ دائمًا } & \multirow{2}{*}{ عناصر الجذب درجة الموافقة } \\
\hline المئوي & النقاط & $\%$ & ك & $\%$ & ك & $\%$ & ك & \\
\hline$r 1, \varepsilon r$ & 1. & $r, r$ & 9 & r. & ir. & $T V, \Lambda$ & rVI & المؤثرات الإنتحركة فى \\
\hline$Y, 1 \leqslant$ & $1 . \leqslant \wedge$ & $r, r$ & 9 & rr,o & $T \pi \varepsilon$ & $T \leqslant, r$ & TOV & الصوت \\
\hline$r \cdot, \wedge$ & $1 . r 1$ & V & ru & $r \Lambda, r$ & $11 \pi$ & $T \leqslant, \wedge$ & roq & وفرة المعلومات البيائية \\
\hline$I \Lambda, V Y$ & $9 Y \Lambda$ & . &. & 71 & TVY & ru & $1 Y \Lambda$ & تصميم الإعلان \\
\hline $1 v, \wedge 9$ & $\Lambda \Lambda \vee$ & r) & $\Lambda \varepsilon$ & 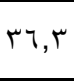 & $1 \leqslant 0$ & $\varepsilon r, \Lambda$ & $|v|$ & ظشهور شالإعلانيات \\
\hline $1 \ldots$ & $\{907$ & & & & & موع الآ & & \\
\hline
\end{tabular}

تلال بيانات الجدول السابق على عدة نتائج من أهمها:

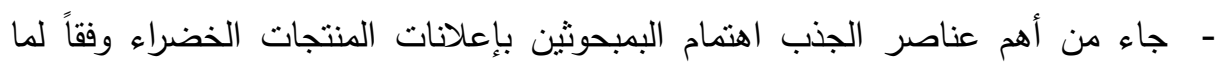

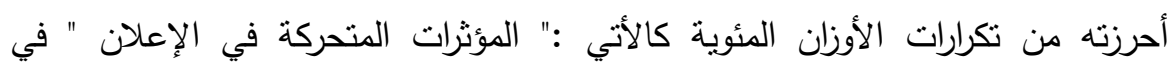

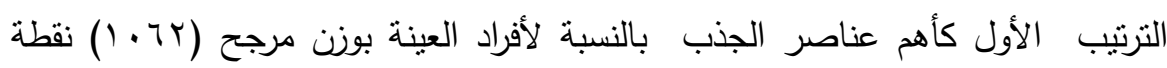

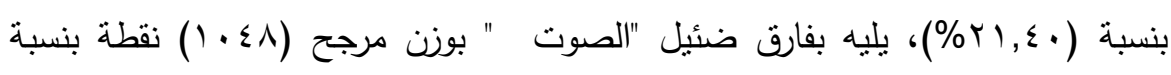

$$
\text { (\% (\%), } 1 \varepsilon)
$$

- أما في الترتيب الثالث فجاء عنصر "وفرة المعلومات البيئية المقدمة بالإعلان" بوزن مرجح

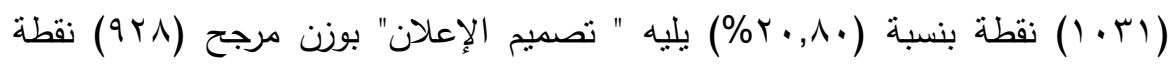

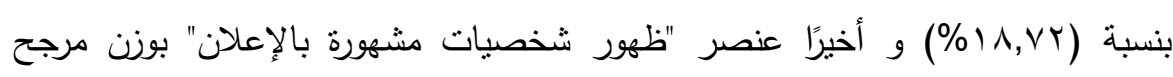

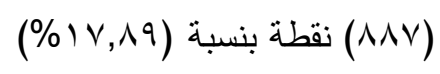


- ويرجع نجاح الاعلانات لان هناك نسب مشاهدة كبيرة للاعلانات وناثر الجمهور المصري باختلاف فئاته لها وهذا في حد ذاته نجاح للاعلان وذللك لانه يساعد على انتتار وتعديل

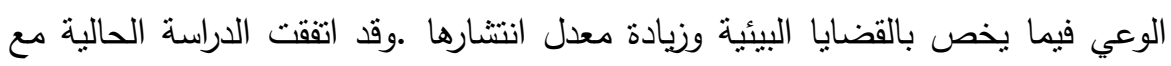

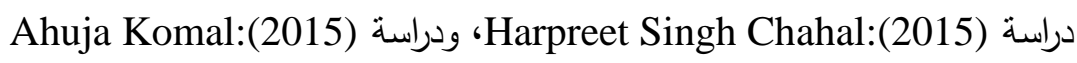
r. مدى قدرة العوامل التي توثر علي جاذبية الإعلان عن المنتجات الخضراء (الصديقة للبيئة) عبر الانترنت من وجهة نظر المبحوثين.

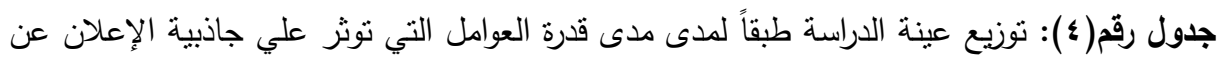

\begin{tabular}{|c|c|c|c|c|c|c|c|c|c|c|}
\hline \multirow{2}{*}{ الترتيب } & \multirow{2}{*}{\multicolumn{2}{|c|}{ |المتوسطابل|لانحراف| المعياري) }} & \multicolumn{2}{|c|}{$\bar{y}$} & \multicolumn{2}{|c|}{ أحيانا } & \multicolumn{2}{|c|}{ دائماً } & \multirow{2}{*}{ العبارات } & \multirow[b]{2}{*}{ r } \\
\hline & & & $\%$ & ك & $\%$ & 5 & $\%$ & 5 & & \\
\hline 1 & . & $Y, V V$ & . & . & rT, & $q r$ & $\vee Y, \Lambda$ & $r \cdot v$ & تصميم الإعلان & 1 \\
\hline 1 &.$\Sigma Y I$ & $r, V V$ & . & . & rr & 94 & $V V$ & $r \cdot \Lambda$ & الألوان & $r$ \\
\hline V & $.7 \cdot \varepsilon$ & $Y, Y)$ & 1 . & $\varepsilon$. & 09,1 & $r r v$ & $\Gamma \cdot \Lambda$ & Trו & الحجم & r \\
\hline r &.$\varepsilon r q$ & $Y, V T$ & - & - & $r \varepsilon, T$ & $9 \mathrm{~V}$ & $\vee 0, \Lambda$ & $r$ & المحتوي & $\varepsilon$ \\
\hline 0 & $.0 \leqslant Y$ & $r, 00$ & r & 9 & $\varepsilon 1$ & $17 \varepsilon$ & 07,1 & YrV & الصورة المرفقة & 0 \\
\hline r & .0 .9 & $r, 7 q$ & r & 9 & $r \eta, 0$ & 1.7 & VI, & rAo & المعلومات البيئية & 7 \\
\hline 7 & $.77 V$ & $Y, 0 \leqslant$ & 9,1 & pq & r & 1.0 & $7 \varepsilon$ & YOT & سـهولة الدخول علي & V \\
\hline$\varepsilon$ & .047 & r & $r, \Lambda$ & 11 & l & IrE & $77, r$ & ryo & سهولة التصفح & $\Lambda$ \\
\hline- &.$\leqslant 0$ & $r, \varepsilon 0$ & & & & & $Y 1$ & 17 & المتر & \\
\hline
\end{tabular}

تدل بيانات الجدول السابق على عدة نتائج من أهمها: - - جاء فى المرنبة الأولى من العوامل التي تؤثز علي الإعلان عن المنتجات الخضراء

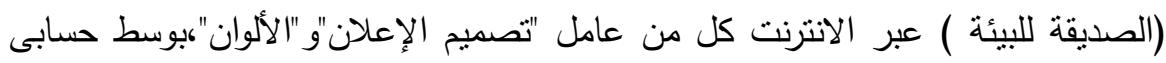
مرجح ونسبة r,VV ، Y حيث جاء إتجاهه بدرجة دائمًا. - - وجاء فى المرتبة الثانية عامل: "المحتوي"، وذللك بوسط حسابى مرجح كT، Y، وانحراف معيارى 9ץ؛، .، ودرجة إتجاه موافق، يليها عامل " المعلومات البيئية" وذلك بوسط

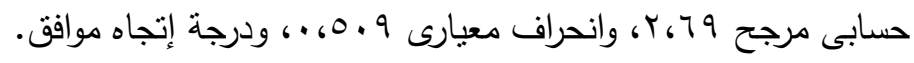

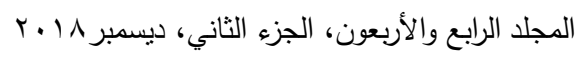


- وجاء فى المرتبة الرابعة عامل: "سهولة التصفح"، وذللك بوسط حسابى مرجح با، Y،

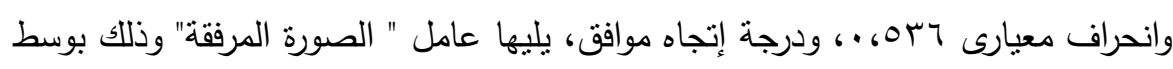

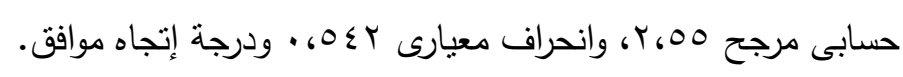

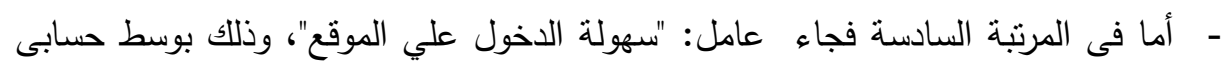

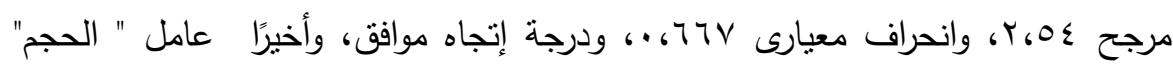

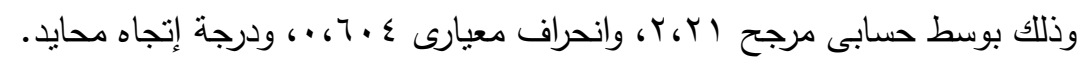

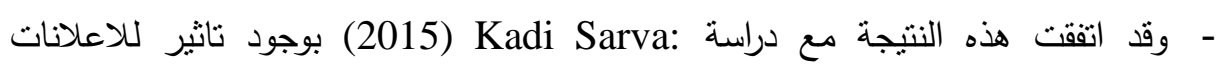

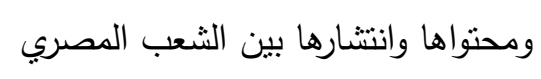
ثالثا: نتائج الفروض

- عدم وجود فروق ذات دلالة إحصائية بين فئتي الدراسة ( ذكور - إناث ) حول مستوي

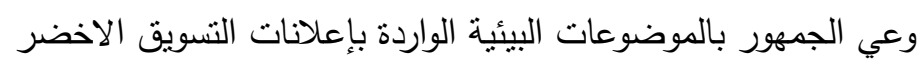

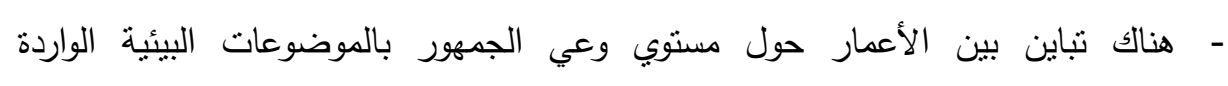

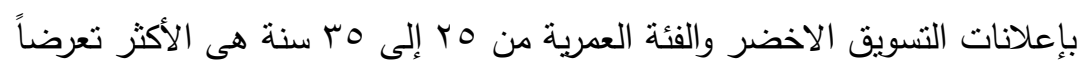

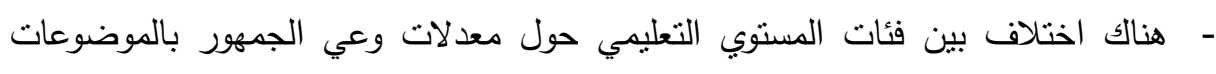
البيئية الواردة بإعلانات النسويق الاخضر والمستوى التعليمى العالي هم الأكثر وعياً

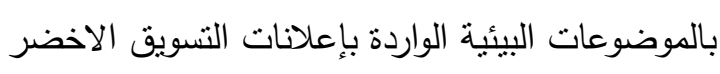

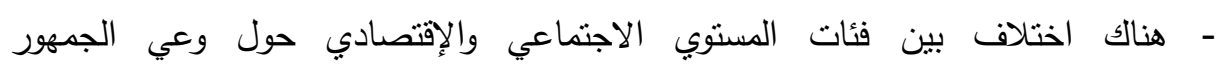

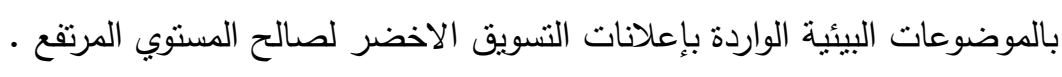

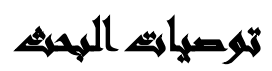

وفقاً للنتائج التي توصل إليها البحث من خلال التحليل الإحصائي لبيانات الدراسة الميدانية وتحليل مضمون الاعلانات البيئية للمنتجات الخضراء، كانت التوصيات مجملةً بما يأني: 
على المستوى التسويقى فى اعلانات المنتجات الخضراء فى وسائل الاعلام المختلفة: ا ـ ضرورة زيادة اهتمام الثركات عند نسويقها للمنتجات الخضراء أو الصديقة للبيئة بالأشكال الإعلانية التى جذبت المشاهدين كالإعلانات الغنائية والتمثيلية وتطويرها بحيث نزيد من

$$
\text { اقناع المشاهدين وتحثهم على تغيير سلوكهم نحوها. }
$$

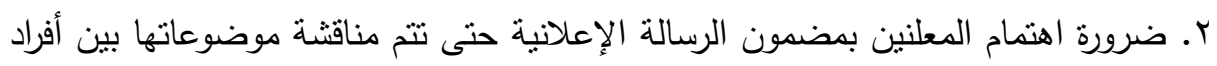

$$
\text { الأسرة وبالتالي تؤثر فى سلوكهم. }
$$

r. ضرورة النظر فى تصميم محتوى الاعلان من حيث مصداقية النص ومدة ظهوره فى في لإنى الاعلان وكذلك توافقه مع ثقافة المستهلك ووعيه لتدفعه فى الوثوق بالرسالة الاعلانية التى منى

$$
\text { يشاهدها. }
$$

ع. ضرورة إنباع الأسس العلمية وبحوث التسويق والاتصال الفعال لتخطيط الحملات الإعلانية للمنتجات البيئية في الثركات ووجود نظام التخذية العكسية للحملات الإعلانية المختلفة لمعرفة الآثار التي أحدثثها تلك الإعلانات التجارية البيئية وما إذا قامت بإحداث

$$
\text { الأثر المرغوب فيه وفي الاتجاه المرغوب فيه. }
$$

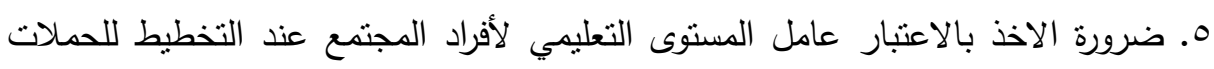
الاعلانية للمنتجات البيئية.

7. ضرورة نوضيح فكرة الإعلان المراد توصيلها للمستهلكينالمستهدفين بدون أي نوع من الاعندانه التعقيد حتى تصل المعلومة بشكل واضح ويقتتع بها أفراد المجتمع. V. ضرورة تطبيق الإبداع وتوليد افكار جديدة في تصميم الحملات الإعلانية للمنتجات البيئية الخضراء لسببين هما: حدة التنافس بين الثركات التى لها نفس المنتج وطبيعة الجمهور المستهدف الذى يعتمد على المقارنة بين سعر المنتج والخدمة المقدة وبين منتجات أخرى.

على المستوى البيئي لاى الثركات التى تنتج منتجات خضراء صديقة للبيئة: ا. على الثركات التى نتتج منتجات خضراء صديقة للبيئة الإستمرار بانتهاج نهج تنبني

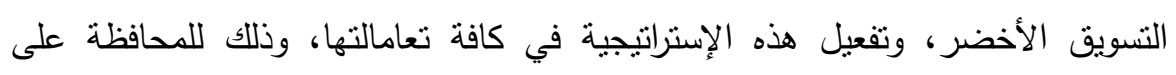

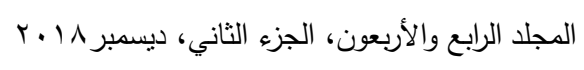


المستهلكين الحاليين، وجلب أكبر قدر ممكن من المستهلكين الجدد، لينعكس ذلك بالمجمل على زيادة الأرباح، وزيادة الحصة السوقية، وتعزيز الميزة التنافسية. r. ضرورة استمرار الشركات التى تتتج منتجات خضراء صديقة للبيئة بتفعيل مفهوم المسؤولية

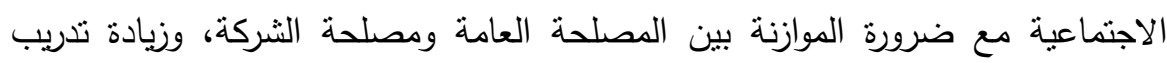

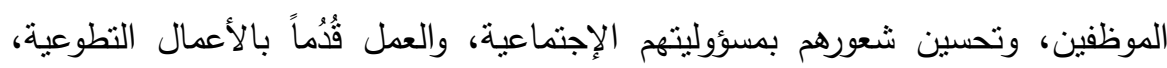
وغيرها من محاور المسؤولية الإجتماعية لما لذلك من أثز واضحتح على ولاءوالجمهور وتحسين الصورة الذهنية لدى المستهكين فينعكس ذلك على تقليل تكاليف الترويج، ويزيد

$$
\text { من الحصة السوقية، ومن الأرباح. }
$$

r. من الضروري الاستمرار بتزويد السوق بالمنتجانالأقل استهلاكاً للطاقة والمواد الخام، وتقديم

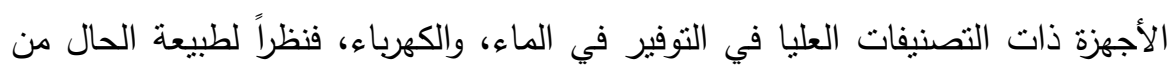

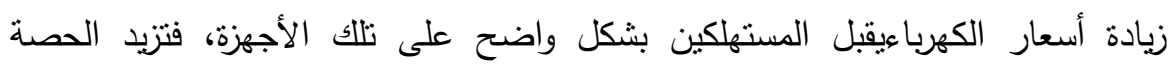

$$
\text { السوقية، وتزيد الأرباح، ويعزز من ولاء الجمهور المستهلك. }
$$

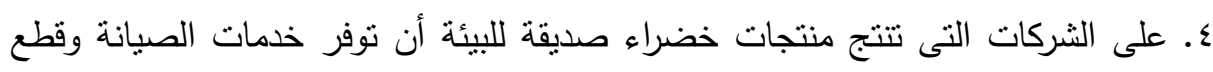

$$
\text { الغيار وسرعة الاستجابة لخدمات ما بعد البيع فى التصليح والاستبدال. }
$$

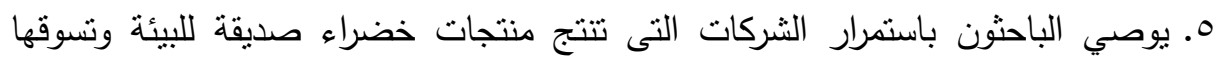
بتوعية المستهلك بيئياً، ودعم برامج تتقيفية بيئية للجمهورعامة وتقديم المعلومة الموتقة لتونة والدقيقة عن أجهزتها، وحتى تبرير السعر مقابل الفائدة المنعكسة من استخدام الأجهزة

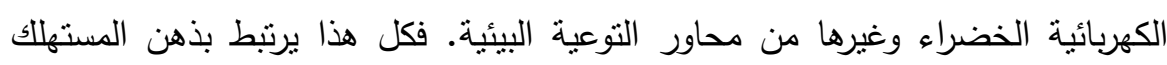
بكفاءة الجهاز، ويزيد من ولاءه للجهاز وللشركة على حد سواء، ويعزز من المغ الميزة لئه التنافسية، فيزيد من الحصة السوقيةومن الأرباح.

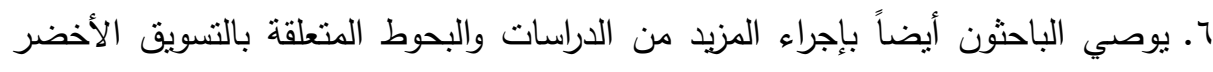

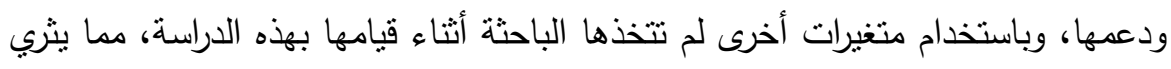

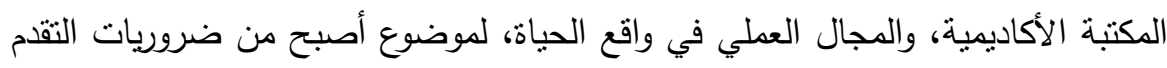
الاقتصادي والاجتماعي ألاوهو التسويق الأخضر. 


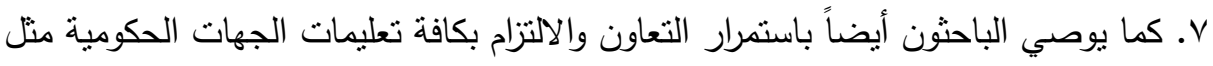

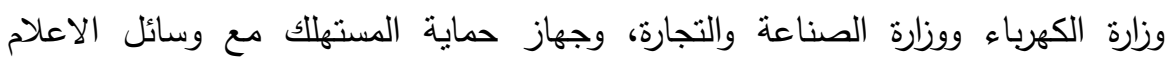
المختلفة، لظهور نتائج هذا الالتزام على المجتمع المصري وأفراده.

\section{zall}

أحمد سليمان محمد: "تحسين الآداء الاستراتيجى للمنظمة الصناعية فى إطار تطبيق الإنيق

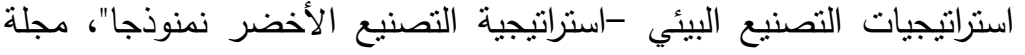

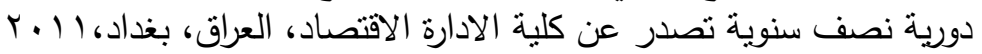

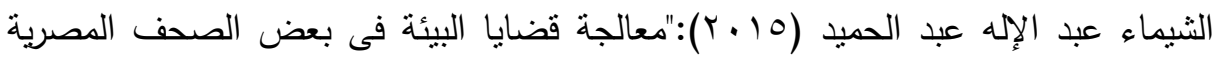

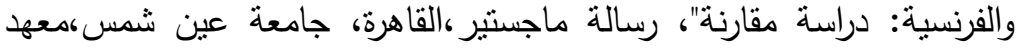

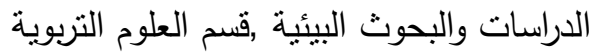

الثيماء محمد سيد(7 1 ץ):"دراسة تحليلية للإعلام المرئي المحلي وعلاقته بالمشكلات البيئية

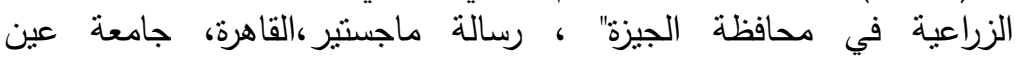
شمس،معهد الدراسات والبحوث البيئية , قسم العلوم الزراعية البيئية

إلهام بوتلجي(1) (1) ج): الصحافة الاككترونية الجزائرية واتجاهات القراء دراسة مسحية لجمهور

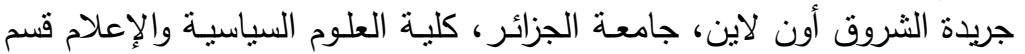

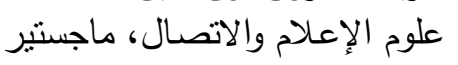

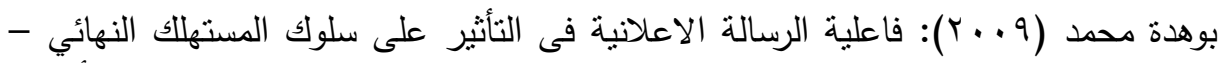

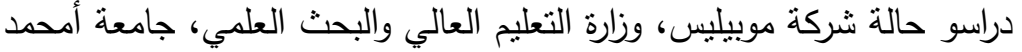
بوقرة بومرداس، كلية العلوم الاقتصادية وعلوم التسيير والعلوم التجارية، الجزائر ، ماجستير،

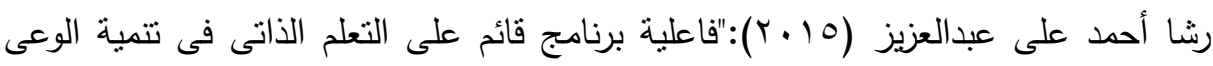

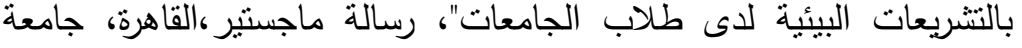

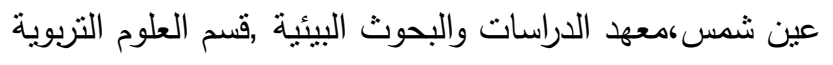

زيزيت مصطفى نوفل:" فاعية برنامج للتنخل المهنى لتتمية الوعى البيئى لدى طالبات المدن

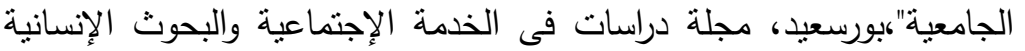

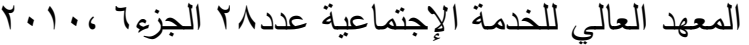

$$
\begin{aligned}
& \text { سامي خشبة:" مصطلحات فكرية"، ص: ror ro ro r } \\
& \text { المجلد الرابع والأربعون، الجزء الثاني، ديسمبر 11 ــ }
\end{aligned}
$$


سامية لحول :" التسويق المستدام كآلية لتحقيق أبعاد التتمية المستدامة "، مجلة دراسات

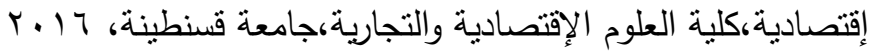

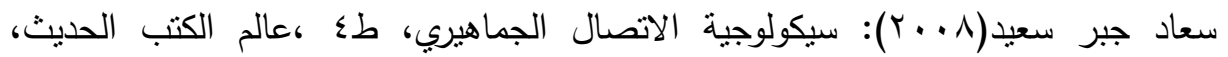

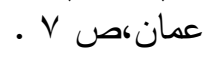

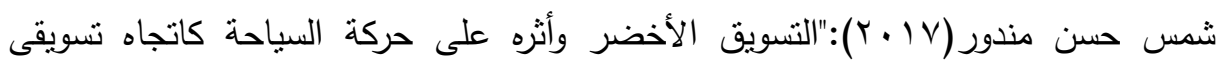
حديث" دراسة ماجستير ، كلية السياحة والفنادق، قسم الدراسات السياحة السية،

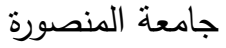

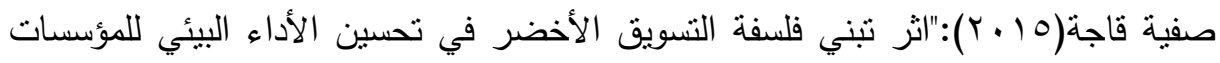

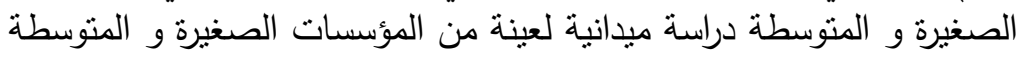

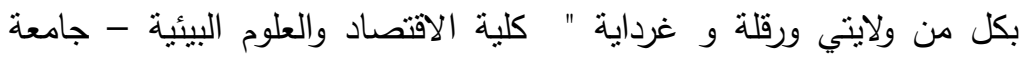
قاصدى مرباح ورقلة - دراسة دكتوراه غير منشورة، الجزائر

عبير تباني: "الحملات الإعلامية الإذاعية الخاصة بالتوعية المرورية في الجزائر - دراسة

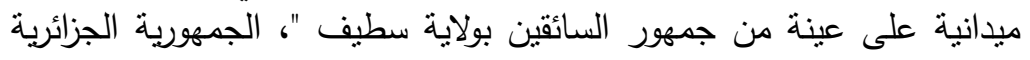

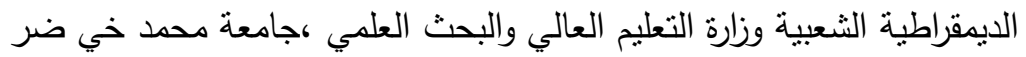

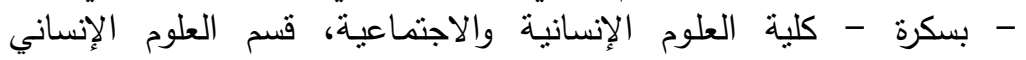
،الماجستير في علوم الإعلام والاتصال الإندانة

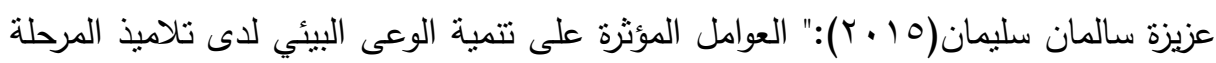

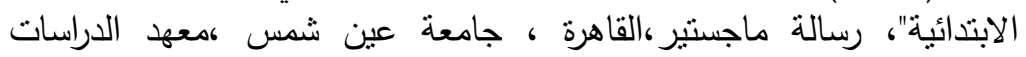

$$
\text { والبحوث البيئية ,قسم العلوم التنربوية البية }
$$

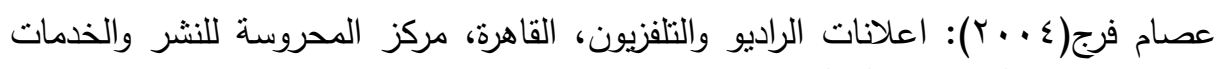

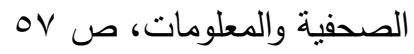

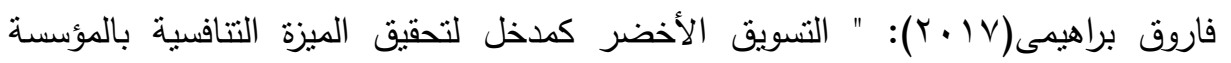

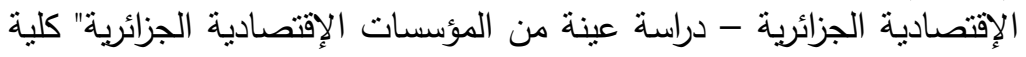

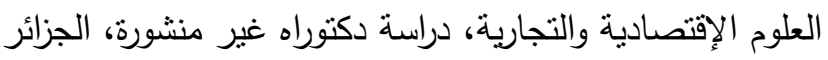

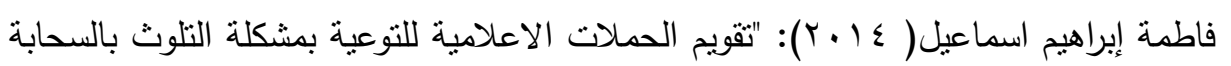

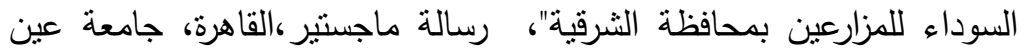

$$
\text { شمس، معهد الدراسات والبحوث البيئية، قسم العلوم التربوية لمارية }
$$

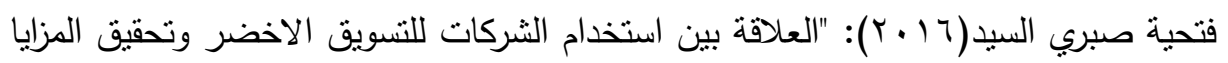

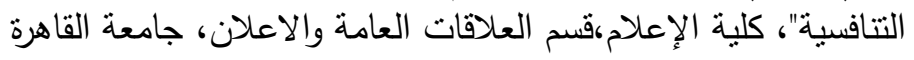

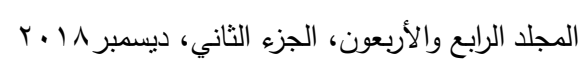


محمد عبد الحميد(؟ . . ب ) ): نظريات الاعلام واتجاهات التأثثر (القاهرة: عالم الكتب) ص rqA

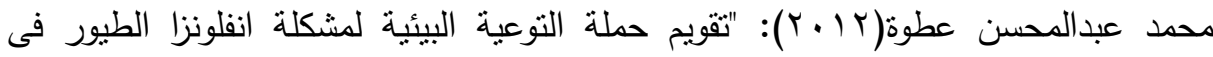

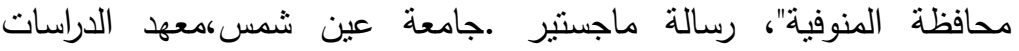

$$
\text { والبحوث البيئية قسم العلوم التزبوية }
$$

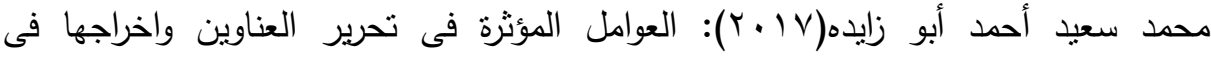

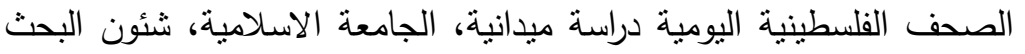

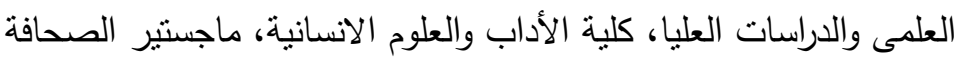

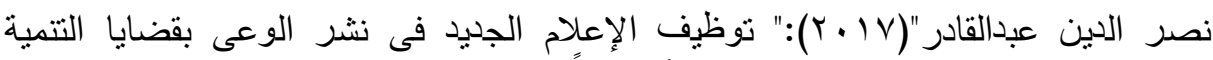

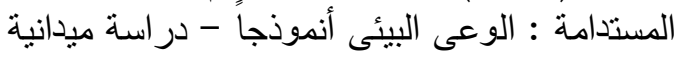

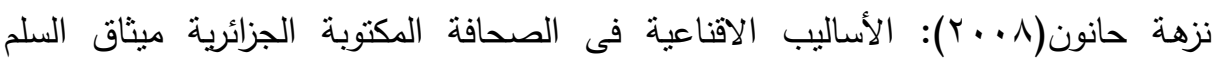

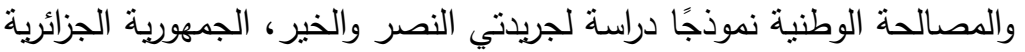

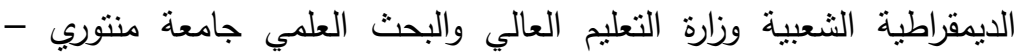

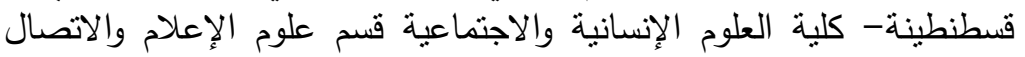

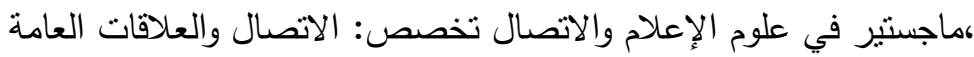

نزيهة وهابي: "المعالجة الإعلامية لقضايا البيئة من خلال الصحافة المكتوبة"، كلية العلوم

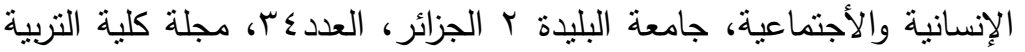

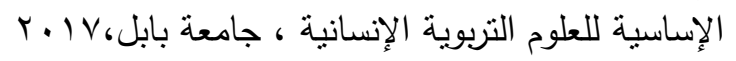

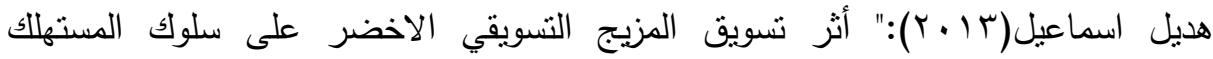

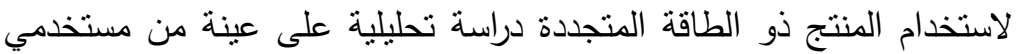

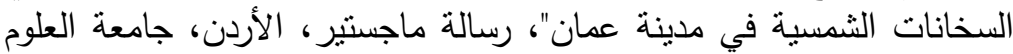
النطبيقية الخاصة

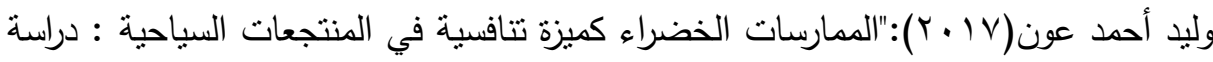

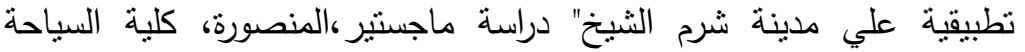

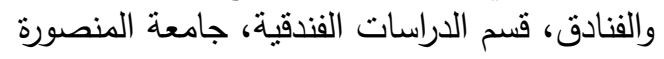

يحيى باسم يحيى(10 ب): قرائية الأخبار فى الصحف الفلسطنية الالكترونية (دراسة تحليلية وميدانية)، الجامعة الأسلامية بغزة، كليـة الآداب ،قسم الصحافة الصافة والإعلان،

$$
\text { ماجستير }
$$

Future (California: Wadsworth Publishing Company, 1995) p. 226

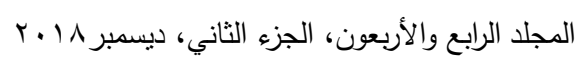


G. Gerbner \& L.Gross. " Living with television: The violence profile" (Journal of Communication, 26(2),1976 ) pp 172-199

Harpreet Singh Chahal (2015): Appeals in green advertising Astudy of factors effecting the persuasiveness of appeals

Hugh M. Culbertson, Cuido H. Stempel: How Media Use And Reliance Effect Knowledge Level,Communication Research, VOL 33, NO.4, 1997, pp.479-60

John Downing, Internationalizing Media theory: Transition, Power, Culture (London: Sage Publications, 1996) p.p.191-193

Kadi Sarva 'The influence ofconsumer perception towards green advertising on green purchase intention, International Journal of Entrepreneurship\& Business Environment Perspectives,Vol.4,No.3, pp.1865-1873,July-Septembe, 2015

Komal Ahuja ‘Study of green Advertising and its impact on consumer purchase intention2015, International J ournal of Applie d Research 2015; 1(7): 39-43 
مجلة العلوم البيئية

معهد الدراسات والبحوث البيئة - جامعة عين شمس لئس

\title{
THE ROLE OF SOME MASS MEDIA IN \\ DEVELOPING AWARENESS OF GREEN \\ MARKETING FOR EGYPTIAN AUDIENCE \\ AN ANALYTICAL AND FIELD STUDY
}

\author{
Merham, S. Ameen ${ }^{(1)}$; Suzan, Y. El-Qeleny ${ }^{(2)}$ \\ and Mohamed, A. Khatab ${ }^{(3)}$ \\ 1) Institute of Environmental Studies \& Research, Ain Shams \\ University 2) Faculty of Arts, Ain Shams University
}

\begin{abstract}
The current study drives at monitoring the impact of green marketing advertisements on audience's awareness of the positive effects of using the environment friend products. The researchers use the descriptive method and these tools as study tools: interview, a questionnaire form employed for the field study, and a content analysis form serving the analytical stud). Sample: the study sample is recruited on purpose from Egyptian audience in: (Cairo, Giza, and Qalubyia governorates) who watch television advertisements and use the internet. It consists of (400) items, aged at 19 yrs. old or above. The study analytical sample is embodied in green marketing advertisements: a total survey of the exposed advs. In different mass media during Ramadan month is administered for three years starting from 2016 to 2018. The study objective is to monitor the impact of green marketing advertisements on audience's awareness of green products and giving easy access information about this issue.
\end{abstract}

The results have been reported:

* There are no statistically significant differences between the two study groups (males-females) regarding the audience's awareness of environmental topics mentioned in green marketing.

* There are significant differences between different education levels regarding the audience's awareness of environmental topics

$$
\text { المجلد الرابع والأربعون، الجزء الثاني، ديسمبر \1) }
$$


mentioned in green marketing, in favor of the higher education level individuals.

* Motional effects in the advs. comes in the first rank, followed by "sound", then "abundance in environmental information presented in the advs." In the third rank, followed by "designing the advs." And finally the "emergence of famous persons".

The most important mass media means viewed by a large number of people is television followed by the facebook on websites.

* The study sample counts on television because of the abundance of environmental information it presents concerning the green products.

* The study is summed up of some recommendations as follows:

* The necessity for increasing companies' concern in green products marketing or environmentally friendly forms of advertising that attract viewers such as advertising, singing, acting and develop to increase the persuasion of viewers and urges them to change their behavior towards them.

Keywords: mass media - developing awarenesss - green marketing Egyptian audience 